Portland State University

PDXScholar

Dissertations and Theses

Dissertations and Theses

Winter 3-1-2012

\title{
Dazai's Women: Dazai Osamu and his Female Narrators
}

Jamie Walden Cox

Portland State University

Follow this and additional works at: https://pdxscholar.library.pdx.edu/open_access_etds

Part of the Fiction Commons, Japanese Studies Commons, Other Rhetoric and Composition Commons, and the Women's Studies Commons

Let us know how access to this document benefits you.

\section{Recommended Citation}

Cox, Jamie Walden, "Dazai's Women: Dazai Osamu and his Female Narrators" (2012). Dissertations and Theses. Paper 132.

https://doi.org/10.15760/etd.132

This Thesis is brought to you for free and open access. It has been accepted for inclusion in Dissertations and Theses by an authorized administrator of PDXScholar. Please contact us if we can make this document more accessible: pdxscholar@pdx.edu. 
Dazai's Women: Dazai Osamu and his Female Narrators

\author{
by \\ Jamie Walden Cox \\ requirements for the degree of \\ Master of Arts \\ in \\ Japanese \\ Thesis Committee: \\ Jon Holt, Chair \\ Laurence Kominz \\ Suwako Watanabe
}

A thesis submitted in partial fulfillment of the

Portland State University

(C)2012 


\begin{abstract}
Dazai Osamu (born Tsushima Shūji) was a post-WWII writer who wrote a number of works using a female narrator. This thesis research focused on the reasons as to why Dazai may have written using female narratives, taking into consideration the time period and social milieu in which he was writing, as well as his own personal history with women. In addition, the history of male authors utilizing female narratives was explored, as well as the ideas of gender in the Japanese arts. Dazai works were also compared with Tankizaki Junichirō's to see how the roles of women in their works differ.

The four main Dazai works analyzed were "Magic Lanterns" (“Tōrō”), “The

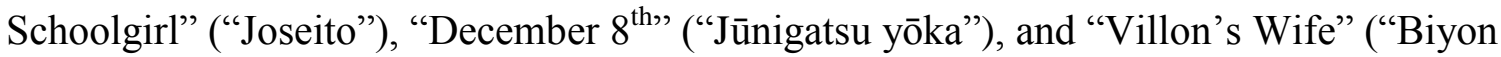
no tsuma"). The conclusion was that Dazai was using female narrators as a different approach to further critiquing himself, with the female narrator being used to critique a Dazai-like persona in the works.
\end{abstract}




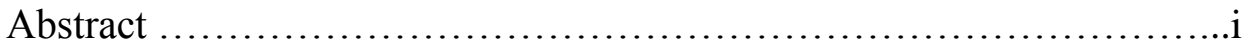

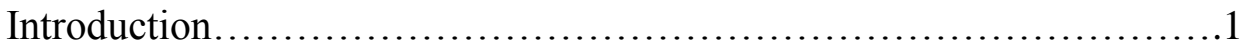

Chapter 1 - Dazai and Women:

Childhood through Death............................................. 3

Chapter 2 - Public Recognition

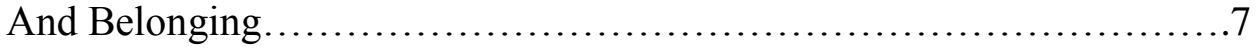

Chapter 3 - Critiquing Women: Dazai's

Essays and Short Stories..............................................11

Chapter 4 - Masked Desires: Gender Performativity in

Japanese Literature and Theater...................................20

Chapter 5 - Dazai, Tanizaki and Voyeuristic Desire.....................24

Chapter 6 - Woman as a Tool........................................33

Chapter 7 - "But You Lack a Proper Upbringing"

The Self-sacrificing Woman in "Magic Lanterns".......................35

Chapter 8 - "Truly, I Do Not Know Who Is the Real Me"

Identity and Recognition in "The Schoolgirl"..........................41

Chapter 9 - "Is He Even Sane?"

The Foolish Intellectual of "December $8^{\text {th }}$ "............................46

Chapter 10 - "Women Don't Know Anything about Happiness or Unhappiness"

"Villon's Wife".

Chapter 11 - Deviation from Established Patterns

The Setting Sun.

Conclusion:

The Role of Women in Dazai's Narratives and Beyond....................60

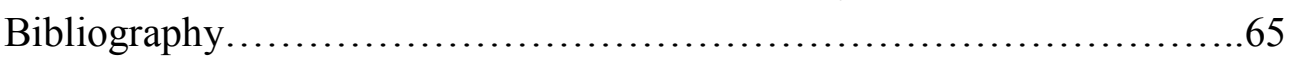




\section{Introduction}

Known for his deeply personal short stories and novels, Dazai Osamu (19091948) made a name for himself not only through his writing, but also through the events of his personal life, of which he made no attempt to hide from the public eye. One of the features of Dazai's writing that sets him apart from a number of his peers at the time is his usage of the female narrator in a number of his stories. The women that Dazai chose to represent as narrators, whether a young housewife with a small child, or a schoolgirl, or even an old woman, are portrayed in a particularly positive fashion. They are thoughtful, intelligent, pensive, strong-willed, hard-working, and creative. This is in stark contrast to the majority of the men in Dazai's stories: violent, alcoholic, selfish, selfdeprecating, drug addicted, and womanizing.

This juxtaposition of strong women and weak men could easily lead readers into assuming Dazai to be some sort of an early male-feminist. But further reading leads to quite the opposite conclusion. Dazai was an author who was very aware of the way he was portrayed in the media, and often responded to critiques or images that were created of him in the media within his own stories. The author, so famous for harsh criticism toward himself, and his autobiographical works, rather than using these women to create a positive example of the modern Japanese female, was on the contrary simply utilizing the women narrators as a tool to further view and critique himself. The only constant within all the works is the strength and intelligence of the female characters portrayed within. I intend to explore Dazai Osamu's relationship with women in his real life, from his relationship with his family, to his marriage, and his number of mistresses, as well as the views of women expressed within a number of his essays. Finally, through a close 
reading of four texts featuring female narrators, a better understanding of Dazai's works, his life, and his views on women in his own literature can be observed. 


\section{Chapter 1 - Dazai and Women: Childhood through Death}

Dazai Osamu was born Tsushima Shūji in 1909, in Aomori prefecture in northern Japan. He was born the sixth son - tenth child overall - into a family that was very affluent, especially compared to the general level of poverty that was prominent in the area. His mother, Tane, was quite frail, and so was not able to take care of Dazai personally. As Dazai himself explains in some of his autobiographical writings about his childhood, however, "his infancy and childhood were passed almost exclusively in the company of women - his wet nurse and his aunt, his four older sisters, and a nursemaid named Take."1 Dazai spent this time around women, mostly, with his older brothers taking a more paternal role than one of typical siblings. In fact, his father passed away in 1923, and his eldest brother Bunji became the head of the household. ${ }^{2}$ Dazai graduated from high school in 1930 and enrolled in the Department of French Literature at Tokyo Imperial University. The same year, an apprentice geisha named Oyama Hatsuyo, who Dazai knew from his high school days, ran away from her geisha house in Aomori to be with Dazai in Tokyo, and they were married soon after. ${ }^{3}$

Marriage to Hatsuyo, however, did not mean that Dazai was faithful or exclusive to her. In fact, in November of 1930, while still married to Hatsuyo, Dazai attempted his first double suicide with a nineteen-year old married woman named Tanabe Shimeko, who worked as waitress in a bar in Ginza. ${ }^{4}$ Though Dazai survived, Shimeko did not. Dazai would later write about this event a number of different times, sometimes

\footnotetext{
${ }^{1}$ James O’Brien, Dazai Osamu, (New York: Twayne Publishers, 1975) 18.

${ }^{2}$ Ralph McCarthy, Self-Portraits: Tales from the Life of Japan's Great Decadent Romantic, (Tokyo: Kodansha International 1991) 10.

${ }^{3}$ Ibid., 13.

${ }^{4}$ Ibid., 14.
} 
indifferently, and others with slightly more of a sense of passion. Either way, Dazai seems to have recognized on some level that Shimeko had sacrificed herself for him and for his love, and the theme of self-sacrifice, particularly by women, is one that appears in a number of his works. Though Dazai was not faithful to Hatsuyo, he rather hypocritically expected nothing more than complete faithfulness from Hatsuyo. As Keene puts it: "Dazai considered a wife's obligation of chastity to be absolute, regardless of the profligacy of her husband." ${ }^{, 5}$ This double standard of morals for Dazai contributed to his life of drinking, drug addiction, love affairs, and illegitimate children.

Of the five total suicide attempts by Dazai, three of them were double suicides. The first attempt, in 1930 mentioned above, resulted in the death of the woman. The second attempt was with Hatsuyo in 1938, after Hatsuyo had an affair with one of Dazai's friends. ${ }^{6}$ After this, the pair committed to going to Minakami hot springs to attempt suicide. In this case as well, Dazai survived, as did Hatsuyo, but the betrayal by Hatsuyo, and the subsequent double suicide attempt resulted in the end of their marriage. ${ }^{7}$ From this point on, not much is known about Hatsuyo, or the end of her life.

The next marriage, and Dazai's last, was with a woman from Shimane prefecture named Ishihara Michiko, in 1939. The marriage was arranged through Dazai's family, and she came to Tokyo to live with him. But just as in the case of his first marriage to Hatsuyo, Dazai was unfaithful to Michiko. The two most prominent affairs both started around the same time in early 1947, first with a woman named Ōta Shizuko, whose diary

\footnotetext{
${ }^{5}$ Donald Keene, Dawn to the West, Volume 1, (New York: Henry Holt \& Co, 1987) 1029.

${ }^{6}$ Phyllis Lyons, The Saga of Dazai Osamu, (Stanford: Stanford University Press, 1985) 40.

7 Dazai chronicles his double suicide attempt with Hatsuyo in his short story "Discarding the Old Woman" ("Ubasute"), published in 1938 in New Current (Shinchō) magazine, a literary magazine popular at the time.
} 
became the basis for one of Dazai's most famous novels, The Setting Sun (Shayō). He also started becoming intimate with a woman named Yamazaki Tomie, a beautician who, according to sources, was death obsessed. ${ }^{8}$ Tomie had been married some years prior, but during the war her husband had been sent by his company to the Philippines, from where he was drafted into the Japanese army. A couple of weeks later, Tomie had received official word of his death. Since that time, Tomie is said to have been infatuated with the thought of dying. She spent a large amount of intimate time with Dazai for over a year, and allegedly, she and Dazai made a death pact as far as a year before their eventual drowning in the Tamagawa River. The bodies of Dazai and Tomie were found on June 19, 1948, which also coincidentally would have been Dazai's thirty-ninth birthday.

The common theme that connects all of these women in Dazai's life - from his wet nurses to his nannies, from his first wife Hatsuyo, to the number of women with whom he had affairs - was their transience within it. His nursemaids and nannies stayed around only as long as they were needed by the family, until Dazai was in elementary school. With Hatsuyo, she was his companion for a long time, but ultimately, she also left (understandably so, it would seem, because she was with him through affairs, addictions, and recovery). Of the other two women with whom Dazai attempted suicide, neither survived, and the first attempt with Shimeko, the young waitress from Ginza, seemed to not affect Dazai in a deeply emotional way. The comings and goings of women perhaps led Dazai to feel a lack of trust towards women; or perhaps it was his mother, who was both physically and emotionally weak to take care of Dazai personally. Perhaps he was influenced by social conceptions of the time, that women were the weaker sex. Dazai had

${ }^{8}$ Lyons, ibid., 51. 
a very strong opinion of women in his writings and was critical in the way he thought women should behave. 


\section{Chapter 2 - Public Recognition and Belonging}

When choosing the winner of the first Akutagawa Prize for Literature in 1935, the main criticisms that were held by the committee about runner-up Dazai were not of his work, but of his personal life. Kawabata Yasunari wrote in Miyako Shinbun: "I regretted that dark clouds in his personal life at the moment seem to be keeping him from expressing his talent more clearly." "9 This affected Dazai, and a string of open letters published in newspapers followed between the two, further criticizing each other's character. If these letters had been written in private, and not discussed in such a public medium, Dazai could have been spared a great deal of embarrassment. Instead, the comments that criticized not Dazai's work - the element upon which the Akutagawa prize should have been given - were replaced with comments on his character in a popular newspaper. For Dazai, an up-and-coming writer at the time, this sort of criticism from Kawabata, a very established writer at the time, had the potential to be particularly detrimental to his budding career.

Dazai was critical of himself, but as noted above, was also very aware of the criticisms that came from others. Although he was born into a rich family in Aomori, Dazai as a teenager was intrigued by the proletarian literature that was becoming more popular at the time. He felt so out of place in his own family that, as a child, he was sure that he was not truly his parents' child, and searched through old records and asked everyone who worked for the family if he truly was their child. ${ }^{10}$ Perhaps this was because Dazai was not part of the working-class, and so was simply interested in what he

\footnotetext{
${ }^{9}$ Edward Mack, "Accounting for Taste; the Creation of the Akutagawa and Naoki Prizes for Literature," Harvard Journal of Asiatic Studies, 64.2 (2004) 313.

${ }^{10}$ Lyons, ibid., 62.
} 
was not a part of. Whatever the case may be, the attraction and affinity to the proletarian literature forced Dazai to recognize that he was born into the class the movement targeted. Although Dazai was born into a rich family, he was "acutely conscious that his father's extensive landholdings and prestige were of no account."11 Dazai was very sympathetic to the proletarian cause, and as such, was critical of his family's wealth (yet he had no problems in spending their money; he lived off of an allowance from his family well into adulthood). The juxtaposition of his ideal, proletarian existence with his wealthy reality made it difficult for Dazai to fit into either category.

Whether he was poor and addicted to painkillers, or living comfortably in his family's home in Aomori, the one constant is that he has always chronicled his life through his writings. His approach to being as open as possible was perhaps a result of his influence by another movement popular in modern Japanese literature: the "I-novel," or shishōsetsu, movement.

Shishōsetsu - a combination of the Japanese words for "I" and "novel" - came to the forefront of Japanese literature in the 1910s. The concept, however, has roots in the early Meiji period (1890s), when influence from the West caused an examination by Japanese writers of what was meant by the "self." As Suzuki remarks about the shishōsetsu movement: "I-novel discourse emerged at a time not only when literary work was thought to be an expression of the author's empirical or 'genuine' self but when the language of the novel was regarded as a transparent medium that could directly represent

\footnotetext{
${ }^{11}$ O’Brien, ibid., 16.
} 
the author's 'self.",12 Essentially, the writing that was being produced by these writers was more or less taken at face value as the writers' own experiences by the readers. And in most cases, these writers were taking inspiration from their own life experiences. This did not mean that everything in the novel was necessarily a true depiction of past events. Lyons states:

The autobiographer is, after all, assembling the self that appears in his autobiography out of a myriad contradictory images; the "I" will necessarily be different depending on the purposes of the autobiographer and his intended audience. Hence, the "facts" are selected and have to have been used with a kind of freedom that is usually attributed only to "fiction"13

The "autobiographer" is, in this case, the shishōsetsu author who bases his story on his own life. While these authors base their stories on their own lives, as Lyon says, there are many different reasons that turn their stories from recollections of memories into a works of fiction. First, the writer keeps the audience in mind. Additionally, because most stories that are published are written with the intention of an elite, erudite audience in mind, there are naturally going to be omissions or inclusions that deviate from the truth. What also needs to be taken into account is that most events deemed important enough to write about are usually extremely emotional ones. If the emotion felt by the author - which would most likely be revisited during the writing of the story - is too strong, the objectivity of the recollection comes into question. In these ways, although the shishōsetsu authors attempted to write semi-autobiographical accounts, there was still an awareness for both author and audience that it was not truly non-fiction.

\footnotetext{
${ }^{12}$ Tomi Suzuki, Narrating the Self: Fictions of Japanese Modernity, (Stanford: Stanford University Press, 1996) 8.

${ }^{13}$ Phyllis Lyons, “Art Is Me': Dazai Osamu's Narrative Voice as a Permeable Self," Harvard Journal of Asiatic Studies 41.1 (1982) 95.
} 
When an author describes a scene, he is not necessarily describing the actual event. What he is describing is in fact only his own perception of the event. In describing the event through only his perception, the author immediately voids the point of view of others who may have perceived the same event but in a completely different way. This creates an inherent amount of fiction in describing any scene, because there will inevitably be some perspective that is omitted. In addition, as Foucault states, to be an author does not "refer purely and simply to a real individual, since it can rise simultaneously to several selves, to several subjects." ${ }^{14}$ Because human beings are everchanging in nature, the "author" who experienced the event and the "author" who is writing about the event are two different people with different outlooks. No matter how closely authors attempt to recreate their past accurately, because they have changed from who they were then to who they now are, there will always be an element of fiction to their work.

\footnotetext{
${ }^{14}$ Michel Foucault, Language, Counter-Memory, Practice: Selected Essays and Interviews, (Ithica, NY: Cornell University Press, 1977) 113.
} 


\section{Chapter 3 - Critiquing Women: Dazai's Essays and Short Stories}

In his essay "Creating Women" ("Nyonin sōzō"), published in 1938 in the journal Japanese Literature (Nihon Bungaku), Dazai Osamu makes a number of daring statements, not only about the portrayal of women in literature, but broad declarations about women in general. The essay begins: "Men and women are two different things... as different as horses and hibachi." ${ }^{, 15}$ He goes on to say that the only author in Japan who describes real women in his novels is "probably [Chikamatsu] Shūkō,"16 the reason for this being that the women in his stories are "exceedingly boring." ${ }^{\text {"17 }}$ Dazai states that the only reason that women in literature are interesting is because they were created by men, and the men in who write these stories are not working from women in real life, but from an ideal of what a woman should be. "Men cannot become women. But men can wear women's clothing," Dazai states. ${ }^{18}$

These statements are Dazai's way of saying that, no matter what kind of woman is described within a story, because the author is a man, the woman being portrayed is not a real one, but rather an ideal. "Even if I am able to vividly describe a woman who begins by greeting someone with 'Oh, it's been a long time,' there is no deep emotion evoked, nor is there any virtue in doing so...if I were to be left alone, I am sure I would simply

\footnotetext{
${ }^{15}$ Dazai Osamu, Dazai Osamu Zenshū (DOZ), (Tokyo: Chikuma Shobo, 1955) Volume 10, 169. Unless otherwise stated, translations are my own.

${ }^{16}$ Chikamatsu Shūkō (1876-1944) was considered one of the foremost authors of the "I-novel" genre; his most famous works include "Letters Sent to a Wife Who Left" and "Black Hair". He had a reputation of being one of the most truly confessional authors of the "I-novelist" movement, so much so that he would often forego the distancing of narration from strong emotion, as was common, and instead his narration: "manage[d] to close the gap between narrative present and story time in a way that suggests a man still at the height of frenzy." Edward Fowler, The Rhetoric of Confession, (Berkeley: University of California Press, 1988) 148.

${ }^{17}$ DOZ, ibid., 170.

${ }^{18}$ Ibid.
} 
continue writing about my ideal woman." ${ }^{19}$ He goes on to reassure male readers not to be discouraged, or feel embarrassed about ever having been called effeminate. "When gentlemen take another look at women, they will certainly be comforted, and think 'Ah, I'm not a woman. Women do not contemplate. Women do not give orders. Women do not create. ${ }^{20}$ In this essay, Dazai is seemingly affirming the numerous criticisms that man has held towards women for hundreds of years. Given the time period in which this essay was first written and published, perhaps the stereotypical views of women portrayed within should not come as a great surprise. However, the sheer bluntness in which Dazai writes makes this a prime example of the kind of attitude about women that Dazai expresses in his oeuvre. It is also important to remember that Dazai was a writer known for his satire and sarcasm, so it is not always wise to take his writings at face value. In fact, if this were the only time that Dazai were to have articulated such views, then this essay could be written off as simply a writer's attempt to create something controversial, or an effort to be satirical. But within Dazai's corpus of work, there are a number of similar examples of his representation of women in an especially negative way.

In another essay, "Lessons for Women” (“Nyonin kunkai”), published in January of 1940 in the literary magazine Works Club (Sakuhin Kurabu), Dazai tells the story of a doctor who transplants the eyes of a rabbit into a blind woman. The operation is initially successful, and the blind woman is able to see. This does not last long, however, and for reasons not clear from the text - although a problem with the stitches, or perhaps with the sterilization of the operation is suspected - and the woman soon becomes blind again.

\footnotetext{
${ }^{19}$ Ibid.

${ }^{20}$ Ibid.
} 
According to Dazai, the phenomenal thing about this story is two-fold. First, that the operation of transplanting rabbit eyes into a woman was successful at all. The second is that, during the time that the woman had the rabbit eyes, she was overtaken by a curious side-effect. Whenever she was near a hunter, she became incredibly frightened and had to run away. Dazai states that, while most people may think that this strange reaction has something to do with the eyes of the rabbit influencing the personality of the woman, this is not the correct interpretation. "It is likely that this rabbit was bred in a hospital, and is nothing more than a domesticated rabbit. There is no reason that a domesticated rabbit would fear a hunter. The tame rabbit had probably never even seen a hunter." ${ }^{21}$ Dazai says the most likely interpretation is that the woman, whom Dazai suspects lived near a skilled rabbit hunter, had previously heard of his great hunting abilities. And when she took on the eyes of the rabbit, it was not the rabbit's eyes that influenced her, it was the idea of the hunter created by her own fears that did. "In other words, it was not the rabbit's eyes that turned the woman into a rabbit. Rather, it was the woman that so loved the eyes of the rabbit, that of her own volition, she decided to become like a rabbit herself.",22 Dazai goes on to give other examples of women attempting to create a sort of physical interaction between themselves and various animals, each time noting the absurdity of each case and of the goals of the women. In one case, a famous movie actress, in an attempt to create for herself a whiter complexion, takes to eating a diet of squid. Dazai cynically notes that, if she were to truly take on the traits of a squid, she would also become as "lithe and transparent" as one, as well. Because the essay is meant

\footnotetext{
${ }^{21}$ DOZ, Volume 3, 190.

${ }^{22}$ Ibid., 192.
} 
to be a moral lesson and an admonition for women, Dazai ends by advising: "Women mustn't forget their prudence." After an entire essay describing the lengths that women will go to an attempt to connect themselves with desirable traits from the animal kingdom in order to better themselves, Dazai essentially tells women to be more prudent and reserved: both of which are commonly seen as ideally feminine traits. As with the first essay, "Lessons for Women" takes a very traditional stance towards the role of women in Japanese society. Although at times exceedingly strict in his treatment regarding women and the rules they must follow, in a different work written soon before his death, Dazai escalates his criticisms even further.

Dazai published "Womankind" (“Jorui”) in April 1948, just two months before his suicide, in the magazine Yakumo. The short story revolves around a young man who had been drafted to work at a factory during the war, but because he was too weak to work was sent back home to his parents. Although the plot deals the main character and narrator Itō, and the confession that he has murdered a woman, this fairly vague set-up is not very well executed, and as a story itself, it is not one of Dazai's best. What makes the story stand out, however, is that there is yet another extremely severe description of women. ${ }^{23}$ Kasai, a friend who has convinced Itō to go out drinking with him at a club, says the following in a conversation:

\footnotetext{
${ }^{23}$ This sentiment by Dazai in "Womankind" was first brought to my attention in Woman Critiqued: Translated Essays on Japanese Women's Writings by Rebecca Copeland, et al, (Honolulu: University of Hawai'i Press, 2006) 69.
} 
For me, the zoological distinction of mankind and apes is wrong. Instead, it should go 'mankind,' 'womankind,' and then 'apes. ${ }^{24}$ The species are completely different. Their bodies are different, so are their ways of thinking, the meanings of their conversations, their smells, their sounds, and their reaction to their surroundings are all totally different. Short of living as women, men will never be able to understand the mysterious world in which women so nonchalantly reside. $^{25}$

It is important to remember that, in this instance, these thoughts belong not to Dazai the essayist, but to one of his characters. Nonetheless, given the fact that Dazai had alleged similar things in the context of the two earlier essays, by this time a pattern has appeared within his works in which Dazai describes what a woman should be. It is possible that Dazai is simply frustrated at the apparent inconceivability of woman's existence, going so far as to say that women belong in a genus that is completely separate from men. Of note, as well, is the order in which the ranking of his new classification system works. Naturally, men come first, then women, then primates. Perhaps the ability to communicate with words or perhaps a long history of cohabitation with men gives "womankind" the slight advantage over primates, but it is clear from Kasai's sentiment that "womankind" takes second place behind men, and that the gap between the two is large.

If we are only to look at these three examples of Dazai's work spanning over ten years, and his apparent views on women within, then it would be simple to classify him as a misogynistic author. Although, within the time period in which Dazai was living and

\footnotetext{
${ }^{24}$ Here, Dazai splits the Japanese word for humankind, jinrui, into two separate categories, mankind (danrui, written with the kanji for "man" and "genus"), and womankind (jorui, written with the kanji for "woman" and "genus"). Dazai continues to use these two compounds to signify the character's opinion of a necessary distinction between men and women, thus necessitating a need for the same kind of distinction in the English translation.

${ }^{25}$ DOZ, Volume 9, 334.
} 
writing, these opinions about women, specifically about progressive women who attempted to succeed in the arts, were commonly negative. In the Taishō Period, there was an increase in visibility of women in society, from the spread of compulsory women's education to a growing women's movement, as well as an increase in the number of popular women's organizations. ${ }^{26}$ By the 1930s, there was even legislation drafted to allow women voting rights and the rights to hold office in local government. ${ }^{27}$ However, the Confucian ideals that held that women were lower socially than men, along with the popular Meiji adage of "good wife, wise mother" (ryōsai kembo: that women's place in society, though important, was confined strictly to the home) had been in place in modern Japanese society for several decades.

The Japanese women's rights ("New Woman") movement of the early 1910s included great female writers and thinkers. Among them was Hiratsuka Raichō, author and co-creator of the women's literary magazine Blue Stockings (Seitō). Raichō and fellow contributors to Blue Stockings (such as Yosano Akiko) were regarded at the time to be intelligent, but were not perceived to be on the same intellectual level as men. In 1912, a reporter from the Tokyo Daily Newspaper interviewed Raichō about the movement, saying "Raichō is very bright for a woman...but when compared with men, she is still [just] a woman. ${ }^{28}$ From her own words, Raichō admitted that the possible confrontations from "advocates of 'good wife and wise mother-ism' was not totally

\footnotetext{
${ }^{26}$ Kenneth B. Pyle, The Making of Modern Japan, (Lexington, Mass: D.C. Heath, 1996) 173.

${ }^{27}$ This law was defeated in the House of Peers in 1931. Had the law passed, however, women who were elected as local officials would still have had to receive permission by their husbands to hold public office. Ibid., 175.

${ }^{28}$ Taken from an article about the "New Woman" movement in the Tokyo Nichi Nichi Shinbun entitled "Myō na Koi," published November 30, 1912.
} 
unexpected. ${ }^{\prime 29}$ Though Blue Stockings was popular, the idea that women could contribute positively to society in a context outside the home was slow to be widely accepted.

From the tone of Dazai's two essays and his other work of fiction, it would be easy for readers to assume that he held these same opinions of women as did the majority of men at the time. The problem, however, lies in the number of works that Dazai wrote in the feminine narrative. Of Dazai's large body of work, which includes over 200 works of both short stories and novels, there are at least a dozen that are written in the female voice. Moreover, a number of his most famous, and most critically acclaimed stories, are works written with Dazai choosing to have the narrator be a woman.

That Dazai chose to have a woman as a narrator for his stories would perhaps not be strange if the women in the story were reflective of the views towards women put forth by Dazai in his essays. However, a majority, if not all, of the female narrators in Dazai's fiction are almost polar opposites of the docile, foolish, boring women that Dazai had laid out in his essays. Although there are over a dozen different works to choose from, the clearest examples of the strong, empowered woman, who seems to stand in such contrast to Dazai's impressions of women, can be found in four of his works: "Magic

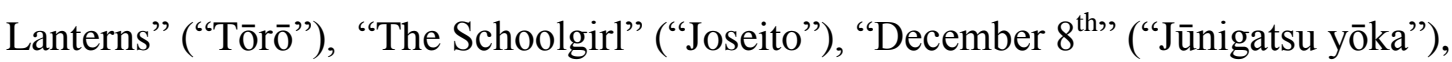
and "Villon's Wife" ("Biyon no tsuma"). If Dazai had such an apparent disdain for women, and thought so lowly of them, why did he choose to write so often from a female

\footnotetext{
${ }^{29}$ Hiratsuka Raichō, trans Teruko Craig, In the Beginning, Woman Was the Sun: The Autobiography of a Japanese Feminist, (New York: Columbia University Press, 2006) 162.
} 
perspective? And why were these women so starkly different from the women Dazai described in his essays? There are a number of different possibilities that can be explored. 


\section{Chapter 4 - Masked Desires: Gender Performativity in Japanese Literature and}

\section{Theater}

By Dazai's time, the phenomenon of men writing as women was not something innovative, either in the context of Japan or in the West. In Japan, one of the earliest instances of a man writing as a woman is the famous tenth century travelogue, Tosa Diary, written between 934 and $935 .^{30}$ In modern instances, famous writers such as Tanizaki Junichirō, Endō Shūsaku, and more contemporary novelists such as Murakami Ryū, have all attempted stories using a female narrator. ${ }^{31}$ While this shows that Dazai, though in a minority, was not the only well-known author that utilized this strategy, simply knowing the tradition does not help in understanding Dazai's intentions through this practice. However, by looking at previous interpretations that have been presented before of male authors writing in the feminine voice, an argument can be made as to whether or not those hypotheses might not also be valid in the case of Dazai's female narratives.

Male authors utilizing feminine narrators as a release for their own sexual desires is more comprehensible in a society where men were not as able to freely and openly express those desires. In Europe, where, for a majority of its history, culture was dictated by Christianity, the exploration of one's sexuality was morally restricted. Japan, essentially unburdened by Christian morals, had more freedom in topics that would be considered taboo in the stereotypical Western context. Originally published in 1948,

\footnotetext{
${ }^{30}$ Donald Keene, Seeds in the Heart, (New York: Henry Holt \& Co., 1993) 361.

${ }^{31}$ Tanizaki's Quicksand (Manji), Endō's Woman's Life (Onna no isshō), and numerous short stories in Murakami's At the Airport (Kūkō nite), are just a few examples using this kind of strategy in modern Japanese literature.
} 
Mishima Yukio's debut novel, Confessions of a Mask (Kamen no kokuhaku) tells the story of a homosexual man struggling to find his place in post-war Japanese society. Confessions of a Mask was hugely popular, and launched Mishima into the status of being one of Japan's most prominent writers. If Confessions of a Mask were the only example of a work about homosexual love in Japanese literature, it would be especially monumental. But Mishima's portrayal of male love was actually a continuation of a Japanese literary tradition which began hundreds of years prior.

In Japan, the tradition of writing about love between men went back at least to the seventeenth century, with the notable example being Ihara Saikaku's The Great Mirror of Male Love (Nanshoku okagami), originally published in 1687. The work describes the romantic relationships between samurai and young boys, as well as between Kabuki actors and their middle-aged patrons. Schalow points out in his introduction to his English translation of The Great Mirror of Male Love that, "popular literature in premodern Japan did not depict male love as abnormal or perverse, but integrated it into the larger sphere of sexual love as a literal theme. Such a tradition had no need for strategies of masking and signaling." ${ }^{32}$ This difference in morals between the West and Japan led to a much more open style of writing in Japan, especially about matters of sex, and sexual desire. As such, the concept of male writers using the feminine narrative to express desires that were societally inappropriate for a male to wish to experience - whether that be a sense of subversion for sexual desire, or an outpour of emotions towards another

\footnotetext{
${ }^{32}$ Ihara Saikaku, trans. Paul Schalow, The Great Mirror of Male Love, (Stanford: Stanford University Press, 1990) 6.
} 
man, masked in the narration of a woman - does not make as much sense in the context of Japan as it does in the West.

Gender exploration - writing or performing as a different gender - occurred often in Japanese arts. An early example of this comes from the Heian period, late in the $11^{\text {th }}$ century with If I Could Only Change Them (Torikaebaya monogatari). The story deals with a brother and a sister who grow up with personalities completely opposite to the typical gender paradigms. "The boy is so shy that he is happy only behind the curtains of the women's quarter... the girl, on the other hand, enjoys nothing more than participating in masculine activities such as kemari and composing poetry in Chinese,"33 much to the dismay of their father. It turns out that the children had been cursed by a tengu goblin, and eventually they are returned to their own proper sex, but not before the son has become a lady-in-waiting in the royal court, and the sister has been married to a woman. In the world of traditional performance arts, Japan's theatrical traditions - mainly Noh and Kabuki - all roles are performed by men. ${ }^{34}$

Specifically in Kabuki, onnagata - male actors who trained specifically to play the role of female characters - were "appreciated precisely because of their artificiality, not in spite of it." 35 These male actors had so perfected playing the role of what a woman should be that they were (and still are) preferred over biologically female actors.

Onnagata also hold a special place in society in that, although they are known to be men in actuality, that reality is suspended in the kabuki theater during performances. This

\footnotetext{
${ }^{33}$ Keene, Seeds in the Heart, ibid., 540.

${ }^{34}$ Although Kabuki was founded by a shrine priestess named Okuni in 1603, women were banned from performing Kabuki on stage from 1629. This ban was not lifted until 1877. S L Leiter, "From Gay to Gei: the Onnagata and the Creation of Kabuki's Female Characters." Comparative Drama. 33 (2000) 495.

${ }^{35}$ Indra Levy, Sirens of the Western Shore, (New York: Columbia University Press, 2006) 233.
} 
suspension of reality inevitably led to a longing for these ideals in real life, which in turn led to an expectation of what the theater-goers saw in the performances to be mirrored in their personal lives. Barring the negative views of women that were prominent in Kabuki roles - one of the most dangerous female emotions being jealousy, an emotion powerful enough to tether them to this world after death - there were many positive, and stereotypically feminine, character traits that were portrayed on stage. One of the most admirable traits that these onnagata performed in particular was that of self-sacrifice. Women, especially wives and mothers, are expected in society to put aside their own happiness for the sake of making others happy, or to work very hard in order to make their partner (or children, etc.) happy. The onnagata kabuki actors exaggerated this stereotype, and through their performances as loving, self-sacrificing women, the female theater-goers in real society felt a sense of pressure to do the same. ${ }^{36}$ Perhaps this was already expected of women, thought to be lower than men in society. ${ }^{37}$

Although there was a certain amount of pressure put on women to act in a certain way from both society and from the arts, we must remember that the majority of writers at this time were still men, so the exertion of societal pressure was, for all intents and purposes, a strictly outward one. But in this way, we can see that gender in the Japanese arts, at least, was something that could be, and was, played with and manipulated. At the same time, the arts were still very much oriented along stereotypical lines of what men and women could or could not do. The late Heian period work If Only I Could Change

\footnotetext{
${ }^{36}$ Leiter gives examples of a number of different Kabuki plays in which the onnagata character sacrifices social standing, or even her life, for the man she loves. One of the examples, Mirror of the Two-Sided Paper Kimono (Kamiko jitate ryomen kagami, 1768), in which the woman, Omatsu, sells herself into a life of prostitution so that her husband can "redeem his prostitute sweetheart from the quarters" Leiter, ibid., 499.

${ }^{37}$ Ibid., 497
} 
Them describes the boy and the girl acting in ways that are specifically not what is expected of their gender, which is where the problems lie.

As Japan began to modernize, the number of female writers increased. Under the influence of Western values, the social opinion that viewed women as the lesser sex began to decrease, albeit slowly. But in literature, women and men were still often imagined within the traditional gender roles of the past, well into the twentieth century. 


\section{Chapter 5 - Dazai, Tanizaki, and Voyeuristic Desire}

In her introduction to Men Writing the Feminine, a collection of essays on early

English and French male writers who wrote in the feminine voice, Thaïs E. Morgan

presents the subject of voyeurism as a possible interpretation of this narrative strategy:

Sigmund Freud defines voyeurism as an act of sadistic looking in which the subject exerts power over someone else by regarding him or (often) her as a sexual object. ${ }^{38}$ Looking never compromises just one action but always instigates a sequence of gazes. Thus, the subject of the gaze derives pleasure not only from looking at someone else as a sexual object but also from imagining himself as a sexual object for the gaze of a third party. ${ }^{39}$

This definition is especially suitable when describing a text that is written by a man from the point of a woman, but that deals heavily with the ideas of love or sexual desire.

Within this definition, a certain pleasure is derived from the reversal of the typical power structure for the male author. The author is aware of how he himself would view a specific (female) character in a certain scenario, and a desire to experience how it would feel to be in that position himself - being looked at in the very same way that he would be looking - is where the source of pleasure for the author is derived. This fascination with a reversed gaze, attainable only through writing as the other sex, is the driving force of the narrative, and the inspiration behind the text.

However, in the context of Dazai's work, this theory of voyeurism in a sexual sense as the driving force does not seem probable for a number of reasons. First, supposing that the goal of writing as the "other" - in this case, a male author writing as a

\footnotetext{
${ }^{38}$ Here, Morgan is quoting Sigmund Freud, "Instincts and Their Vicissitudes" in The Standard Edition of the Works of Sigmund Freud, Volume 14, 125-140.

${ }^{39}$ Thais E. Morgan, Men Writing the Feminine: Literature, Theory, and the Question of Genders, (Albany: State University of New York Press, 1994) 6.
} 
woman - is to experience the other side of the traditional binary of power present within men and women at the time, then logically, that traditional binary would be present in the text. As mentioned before, the common thread within these female-narrated works by Dazai is that there is a subversion of that binary, which would not function as an accurate representation of the experience of women at the time.

Second, voyeurism involves sexual pleasure in knowing that while one gazes, they are being gazed at. The voyeur derives pleasure from knowing that there is a possibility that he will be gazed upon. If Dazai were using a female narrator in order to experience being the recipient of this voyeuristic gaze by men, and sexual desire were the most central feature for him, then sexual desire would most likely take a much more prominent place in the narrative. But when Dazai chooses to write as a female narrator, the subject of sexual desire is rarely broached. In addition, because Japan has had a long literary tradition of openly discussing sexuality and sexual desires, male authors were more likely to simply discuss a sexual desire - whether that be of exerting power over a woman, or having a woman exert power over them - outright, without the need to employ a narrator of the opposite sex.

One such author who did not shy away from sexuality or from showing that sexuality off in many of its forms was Tanizaki Junichirō (1886-1965). Tanizaki was famous for writings of an overt, hedonistic, and sexual nature. According to Tanizaki himself in "Tokyo o omou": "I was basically uninterested in politics, so I concerned myself exclusively with the ways people live, eat and dress, the standards of feminine 
beauty, and the progress of recreational facilities. ${ }^{, 40}$ Essentially, Tanizaki made his apparent fascinations and fetishisms of the female body very well known, as they commonly appeared as themes in his writings. Tanizaki does not often utilize female narrators in his works. He creates a clear and obvious tone of sexuality and an awareness in the reader that sexuality is on display in his works from beginning to end.

Most notably, a reversal of power in a relationship between a man and a woman is often present. One such story is "The Tattooer" ("Shisei”), published very early in his career, in 1910 in New Thought Tides (Shinshichō) magazine. The hedonistic story tells of a tattoo artist named Seikichi, who spies a beautiful woman's foot dangling from inside a palanquin, and from that one glimpse becomes infatuated. Of the foot the story says “this, indeed, was a foot to be nourished by men's blood, a foot to trample on their bodies. ${ }^{.41}$ The theme of feet is one that appears often in Tanizaki's works. The foot in question, however, belongs to quite a meek young geisha, who, though reluctant to initially receive a tattoo from Seikichi, eventually gives in. Seikichi then spends an entire day painstakingly tattooing a large spider onto the back of the young girl. This scene takes up the majority of the narrative, and shows a clear dominance by Seikichi over the young woman, who has been drugged with a powerful anesthetic. Seikichi also is obviously enjoying exerting this power over her, so much so that it has been likened to "a kind of rape. ${ }^{, 42}$ When the tattoo is finally finished and the young girl becomes fully cognizant again, she comes to accept the destiny that was laid out to her, that she was meant to "trample on bodies" of men. She quickly turns this new-found sexual desire

${ }^{40}$ Keene, Dawn to the West, Volume 1, ibid., 721.

${ }^{41}$ Ibid., 727.

${ }^{42}$ Ken Itō, Visions of Desire: Tanizaki's Fictional Worlds, (Stanford: Stanford University Press, 1991) 57. 
(and desire for power) on Seikichi. In short, the man who had the power to transform the woman into what he desired succeeded in doing so, and at the same time lost the power that he was able to exert over her (at least, physically).

Another story that has a seemingly obvious reversal of power is in Tanizaki's 1924 novel, A Fool's Love (Chijin no ai, also translated as Naomi), serialized in the Osaka Morning News (Osaka Asahi Shinbun). Unlike "The Tattooer," which is narrated by a third-person narrator, A Fool's Love is narrated by a male narrator who is also one of the main characters. A Fool's Love tells the story of a twenty-eight year old man named Jōji (the narrator), who finds himself attracted to a fifteen year old young woman named Naomi, who works in a café in Asakusa. ${ }^{43}$ Jōji decides that Naomi, a girl from a poor area, who does not have much money, should be bred into a proper (read: Western) young woman. Around this time in Japanese history, Japan was already in the full-swing of modernization and westernization, and although the 1920s proved to be a time of political turmoil, Japan was still fixated on all things Western. This included the narrator Jōji, who begins pouring the majority of his time and resources into Naomi's social grooming. Eventually, Jōji gets what he wants, and Naomi is successfully turned into a Westernized woman. This also means that, instead of engaging in a romantic relationship with her now-husband Jōji, Naomi makes them move from Tokyo to Yokohama - a very cosmopolitan city - and spends her time with foreign men as her guests in their house, while Jōji sleeps in the other room. This is not to say that Jōji does not desire Naomi; in one section of the narration, Naomi undresses in the same room as Jōji, but Jōji is most

\footnotetext{
43 According to Itō: “'Cafés,' which were not cafés at all but forerunners of the modern hostess bar, were all the rage in Tokyo during the Taisho period, and [hostesses at the cafés] were well on their way to surpassing geisha as the preferred comforters of the male ego.” Ibid., 81.
} 
interested in a certain part of her anatomy: "The sight of her bare feet tempted me more than anything else. I tried not to look, but I couldn't help it. Of course she was doing this deliberately. Wiggling her feet, she watched my eyes closely." ${ }^{44}$ But Naomi, although she spends a good deal of time with foreign men, is not attracted sexually to Jōji; his attempt to create a Western woman with Western tastes (in everything, including men) was truly successful. Though unsatisfied at times with the relationship, Jōji is ultimately content with the arrangement that he and Naomi have together, even though it seems that he has lost all power in the relationship to her.

In both examples (and in others of Tanizaki's extensive collection of work), it appears that the man, who initially started in the position of dominance, ends up in a subverted position to the woman at the conclusion. But in reality, it is the man who gets the last laugh, because his ideal creation has come to fruition. In both stories, the women are not necessarily destined for the roles in which they find themselves at the end; it is rather an act of will and an exertion of power - monetary, social, or otherwise - over the women that creates a binary in which the power actually never truly leaves the male character. About Seikichi in "The Tattooer," Itō states, quite astutely: “The artist's yearnings encompass both the urge to dominate and the wish to bow before a transcendent authority... his submission validates his own mastery. ${ }^{.45}$ Whether or not there really is a shift of power in the relationships present in Tanizaki's works, perhaps an even more important theme is the sexual drive that motivates a majority of his characters.

\footnotetext{
${ }^{44}$ Tanizaki Junichirō, trans. Anthony Chambers, Naomi: A Novel, (San Francisco: North Point Press, 1990) 205-206. ${ }^{45}$ Itō, ibid., 57.
} 
Sexual desire often plays the part of catalyst in Tanizaki's works, and the voyeuristic quality of the narration also plays an important role.

In addition, because in neither of these stories is the narrator a woman, the story is being told from a point of view that is not their own. This lack of female perspective in the narrative further reveals that it is in reality the man who has remained in power all along. In "The Tattooer," although the story is told through a third-party narrator, when the emotions or thoughts of the characters are described, it is often Seikichi's point of view that is expressed, and not that of the young geisha. In A Fool's Love, Jōji tells the story solely through his own perspective. Although there is not a sense that anything is being purposefully omitted from the narration, the fact that the entirety of the text is told only from Jōji's point of view - with the only opinions that come directly from Naomi being through her dialogue - innately skews the bias of the text towards the male narrator, leaving the opinions and thoughts of Naomi largely unseen. In this way, the sexual desire that is portrayed in the two works is from the male perspective, and not from the women themselves. This is the case even when it is the women who are taking part in - or even initializing - these desires and behaviors. In both examples of Tanizaki's works, the sexuality is both explicitly described and oriented towards the male character.

Conversely, in Dazai's narratives in general the role that sexuality plays is not as strong as it is in the works of Tanizaki. The same is true for Dazai's female narrated works, as well. However, although sexual desire is not as openly discussed as in Tanizaki's works, there are a few instances, like in his short story "The Schoolgirl," where sexual desire from a female perspective is prevalent in the narrative. Originally 
published in 1939 in Literary World (Bungakkai) magazine, "The Schoolgirl” is narrated by a young girl who is getting her first tastes of a yearning for the opposite sex:

The face of the gardener who has been coming the past two of three days to tend our garden flickered before my eyes. I couldn't help myself.

Although he's nothing but a gardener there's a very different feeling about his face. To exaggerate a little, he has the face of an intellectual. His dark complexion gives him a decisive mien. He has nice eyes. His nose is very pug[-like], but that matches his dark coloring and gives him an air of strong will-power. He has well-formed lips. His ears are slightly dirty. As for his hands, they indeed give him away as a gardener, but his face, shaded from the sun by a black soft felt hat that he wears deep down over his eyes, makes me feel that he's wasted as a gardener. ${ }^{46}$

The young woman, whom it seems has grown up in a higher social class than a gardener, has a clear and intense interest in the man. While she describes the gardener, the infatuation becomes obvious, as she dismisses perceived imperfections (such as a pug nose) as a symbol of strong-will. In addition, there is a high amount of detail that she can remember about someone like a gardener, especially one that has only come around the house a small number of times. Even more prominent is the young woman's commentary on the gardener's hands, and a feeling of sadness that a man with a face such as his does not have a better life than that of a gardener. She shows compassion nearing pity for a man with whom she has never spoken. The overall sentiments are very strong, but the desire found within is not necessarily an erotic one. Rather, Dazai has skillfully described the interim period of adolescence, where the distinction between love and lust is not yet clear. The narrator is most likely experiencing the first inklings of an erotic desire for a man, instead of a prepubescent infatuation that is devoid of sexual desire. But because

\footnotetext{
${ }^{46}$ Dazai Osamu, trans. Lane Dunlop, "The Schoolgirl," (Newcastle upon Tyne, England: Northern House for Stand Magazine, 1992) 9.
} 
these feelings are new to her and are not yet fully realized, the desire described within does not come across as explicitly sexual.

In “Villon's Wife," published originally in March, 1947, in Outlook (Tenbō) literary magazine, Dazai also addresses sexuality in a very limited way. Sacchan, the main character, is married to and has a child with Ōtani, a writer who is more concerned with racking up a debt at the local tavern than being with his wife or son. Although the two are together in marriage, the general sense taken from the narrations, and the actions that make up the story, is that Sacchan feels more obligation than love towards her husband. Or, more likely, the love is still present, but has been impeded by the need to be a constant caretaker for Ōtani, and to clean up after his various transgressions around town. The subject of sexual desire for her husband is never broached in the narrative. In fact, the only time that sex is mentioned at all is when Sacchan is raped by a customer at the bar where she works. Though the events leading up to the rape and what happened at the tavern are recorded in the short story, there are only two sentences in the entire narrative that relate to the actual rape itself: "Toward the end of the New Year season I was raped by a customer" and "the next morning at dawn he took me without ceremony." ${ }^{, 47}$ Even the act of Sacchan being violated in such a way does not bring her to discuss the sexual nature of what happened. It is not that she ignores it, but the fact that such an action is not cause to bring up sexuality in the narrative is surprising. This glossing of details could also be viewed as the narrator's reaction to having been raped, or her not wanting to relive the scene, even when the rest of the story is very confessional;

${ }^{47}$ Dazai Osamu, trans. Donald Keene, “Villon's Wife,” Modern Japanese Literature: An Anthology, Ed. Donald Keene, (New York, NY: Grove Press, 1994) 412 and 414, respectively. 
either way, the glossing of details makes the incident even more believable. Alternatively, O'Brien theorizes that "the times have made her so numb that a rape seems no more significant than buying a bun. ${ }^{48}$ In essence, the long time spent caring for her husband, and the emotional toll that came along, has dulled her senses to the point of emotional void.

In Dazai's work, sex and sexual desire are not common themes. However, considering the works that are narrated by a female character, the lack of sexually explicit conversation actually creates a more believable narrative. The majority of the characters that Dazai uses as narrators belong to the middle or upper class society. It is only natural, then, that women of that class, at this period in Japanese society, would not be open to discussing their sexual desires in the same way as men. For example, the narrator in "The Schoolgirl" does not belong to the highest social class in Japan, but she does realize that there is a difference between her and the gardener for whom she has so much affection. In this sense, it is easy to see how she would choose to be more careful about how she speaks and presents herself, even in the context of a story that is almost exclusively internal dialogue. In "Villon's Wife," Sacchan does not have very much money due to her husband's drinking and lack of income, but there is a sense throughout the narrative that she attempts to reach above and beyond her social class, both in the way she speaks and through her actions.

${ }^{48}$ O’Brien, ibid., 127. 


\section{Chapter 6 - Woman as a Tool}

The inherent fiction present in shishōsetsu literature, as previously mentioned, was perhaps not lost on Dazai. Dazai was not very fixed with descriptions of his own personal history, often changing facts, locations, or people to better fit a story. ${ }^{49} \mathrm{He}$ could even create characters that, at first glance, did not have any similarities to the author, but who in fact were very similar to Dazai in some way or another. His flexibility with his own past, as well as his awareness of how he was perceived in the media and by other authors, allowed Dazai to not only narrate from the perspective of a struggling author, or of a son of a wealthy landowner, or of an addict and alcoholic, but from all of these at once, because Dazai was all of these at one point in his life or another.

Dazai had an acute sense of being an outsider - which garnered him an ability to see aspects of himself from a perceived "other" person - so he did not need a narrator just like himself in order to critique himself or to express his emotions. In his female-narrated stories, Dazai chose not to use direct models of himself, but to critique himself through the views of others, namely, through the women in the story.

Dazai's women were not meant to be representations of how women should be treated, or, of how women actually felt and thought at the time. Rather, they were simply another means at Dazai's literary disposal to further critique himself. This self-critique came in many forms; in some of his stories, the female narrator is very similar to Dazai, while other narrators are less like him. In others, the female narrator is used almost

\footnotetext{
${ }^{49}$ Keene notes that Dazai has no less than five different descriptions of the same event - his love suicide on November $26^{\text {th }}, 1930$ - in stories written between 1932 and 1948 . Though the main events of the story are largely the same, the age and occupation of the woman, as well as the emotion tied to the event, change with each retelling. In this way, Dazai's willingness to change events and his flexibility with these events, is shown. Dawn to the West, Volume 1, ibid., 1029-1030.
} 
exclusively as a way to negatively critique artists or literary figures that bear striking resemblances to what we know about the real Dazai and his life. And in other stories, there are events that closely resemble events related to Dazai's own life. Ultimately though the following four stories - presented chronologically - all carry the common thread of Dazai using female narrators as a literary tool for further introspection and selfexploration on the part of Dazai. 


\section{Chapter 7 - "But You Lack a Proper Upbringing" - The Self-sacrificing Woman in "Magic Lanterns"}

The year 1935 was marked with both good and bad times for Dazai, in both his personal and professional lives. As Lyon's states, “the year 1935 was a pivotal one for Dazai." 50 Although he had been writing since he was in high school, he had found real popularity in the social sphere only a couple of years prior, when his story "Losing Ground" ("Gyakkō") was published in the February issue of Literary Arts (Bungei) Magazine. Shortly after, in April, Dazai suffered an attack of appendicitis and was hospitalized. After the operation, Dazai suffered from peritonitis, and on top of that, a lung ailment also began to flare up again. For these many ailments, he was prescribed Pavinal, a form of morphine (similar to oxycodone), which helped alleviate the pain, but to which he also became addicted. It was so bad that, by July, when his short story "Losing Ground" had been nominated for the first ever Akutagawa Prize, Dazai was deeply addicted. This, according to the committee responsible for awarding the prize, was one of the main reasons that Dazai was not the winner, which only furthered his feelings of despair. $^{51}$

One of the bright spots is that Dazai was able to publish his collection of short stories, The Declining Years (Bannen) in November, and there was even a celebration held in his honor in June of 1936, but at the event, "the guest of honor was a sorry sight." ${ }^{, 52}$ Still addicted, his friends hoped to get him treatment, but for the rest of 1936 , through 1937 and into 1938, Dazai wrote very little, and published even less. One of

\footnotetext{
${ }^{50}$ Lyons, ibid., 36.

${ }^{51}$ Mack, ibid., 313.

${ }^{52}$ Lyons, ibid., 39.
} 
these stories published was "Magic Lanterns" ("Tōrō”), published in the December issue of Young Grass (Wakakusa), a literary magazine geared towards younger readers. ${ }^{53}$ Although it is a very short story, it draws upon many elements that are familiar to Dazai's own life, while at the same time presenting a narrative of self-sacrifice in the name of love, all from the perspective of a young woman.

The narrator of the "Magic Lanterns," Sakiko, is a twenty-four year old woman who, from the beginning of the story, draws the reader in with her explanations of her current social standing as an outsider: "The more I talk about it, the more suspicious people become. Everyone I meet is wary of me. Even when I go to see them for the simple pleasure of their company, they greet me with the strangest of looks, as if wondering why I've come. I find it unbearable." ${ }^{, 54}$ It is clear from the first page that Sakiko is a social pariah. What is not immediately clear is how she became that way. She goes on to say that she is poor, but also that she does not live in a very rich neighborhood, so there must be something else that is making people avoid her so readily. As the narration unfolds, it comes to light that Sakiko is in love, with a man named Mr. Mizuno. Mr. Mizuno is, by Sakiko's accounts, an orphan and a college student. He is also five years Sakiko's junior. But Sakiko says "I had no alternative," and that she is "the kind of woman who falls in love at first sight." 55 And Sakiko is indeed in love. So much so, that when Mr. Mizuno tells her that he was invited swimming, but cannot afford a swimsuit, Sakiko risks arrest in order to steal one for him. This results in her being caught, and

\footnotetext{
${ }^{53}$ DOZ, Volume 2, 372.

${ }^{54}$ Dazai Osamu, trans. Tomone Matsumoto, "Magic Lanterns," The Shōwa Anthology: Modern Japanese Short Stories, Ed. Van C. Gessel, (Tokyo: Kodansha International, 1985) 39.

55 Ibid., 41.
} 
eventually released, but it also leads to Mr. Mizuno distancing himself from her, citing his great ambition in life and her lack of a proper upbringing as his reasons for leaving her. In the end, Sakiko is left as a social outcast, and Mr. Mizuno disappears from her life completely.

In this story, Sakiko performs actions that both conform to and challenge stereotypes of women. First and foremost, the entirety of the plot focuses on her sacrificing everything she has for her love. As stated before, the idea of women sacrificing themselves for the ones they love, while not a strictly Japanese phenomenon, had been seen in Japanese literature and theater for hundreds of years by the time Dazai wrote "Magic Lanterns." But in this short story, readers are able to experience not only the action itself, but also the inner-dialogue of Sakiko as she decides that this is what she must do in order to protect Mr. Mizuno. Mr. Mizuno, by Sakiko’s own account, has already confessed that "his most enjoyable moments were when he went out walking with me." 56 This puts Sakiko in the position to keep his happiness going, whether or not it is beneficial to her. She steals the swimsuit, is subsequently arrested, is hit in the back and face in the process, and is brought in for questioning. During the questioning, Sakiko begins a speech that takes up a large amount of the text. Part of this speech later is found in a newspaper article under the headline "ELOQUENT SPEECH MADE BY YOUNG DEGENERATE LEFT-WING WOMAN." ${ }^{, 57}$ Her speech reveals that Sakiko does not care what happens to her, as long as Mr. Mizuno ends up happy:

\footnotetext{
${ }^{56}$ Ibid.

${ }^{57}$ Ibid., 43.
} 
Mr. Mizuno is a good man. He'll soon make a name for himself. I'm sure of that. I don't want him to be humiliated. He had promised someone he'd go swimming, and I wanted to send him there dressed like everyone else. What's so wrong with that? I'm a fool. A fool! But I'll make a fine man out of him, and present him for your inspection. He comes from a good family. He's different from other people. I don't care what happens to me as long as he goes out into the world and does well. Then I'll be happy. I have to help him. ${ }^{58}$

Sakiko's confessional pleas to the police officer show exactly how fragile an emotional state she is in. Sakiko goes from justifying her actions, and not seeming to understand why she has been taken in, to calling herself a fool. Ultimately, she does not seem to regret what she has done. Most of all, her intent is to make Mr. Mizuno into someone important. What happens to her is clearly not as important as what will eventually happen to him. Sakiko is willing to sacrifice everything for the man she loves.

In return for Sakiko's actions, Mr. Mizuno writes her a letter. In the letter, Mr. Mizuno tells Sakiko that, despite his best attempts at correcting her, she lacks a proper upbringing and therefore must atone for her sins by apologizing to society at large. In the end, he is convinced that he will become something great. He also orders Sakiko to burn the letter and the envelope, effectively ridding all evidence of him in her life. This section is where we most clearly see Mr. Mizuno, because he is speaking directly though the letter, instead of being transmitted through Sakiko.

Two aspects of "Magic Lanterns," self-sacrifice on the part of the woman and the man's dismissal of her, were also elements in Dazai's personal life. A number of experiences that Dazai had up to this point in his life could have been taken as inspiration for this story. The women in Dazai's life frequently had to sacrifice themselves for him.

${ }^{58}$ Ibid., 42. 
His wife Hatsuyo gave up her life in Aomori working at the geisha house to come and live with Dazai. Dazai repaid this act of love with addiction and affairs. Towards the end of Dazai's second marriage to Michiko, when Dazai began his affair with his mistress Tomie (the woman with whom he was to commit his final double suicide), he almost completely abandoned his wife and their children, and spent the majority of his time living with Tomie in a separate house.

On the surface, Dazai and the character of Mr. Mizuno do not seem to have many similarities. The comparison comes, however, in the way in which both Mr. Mizuno and Dazai rid themselves of the women in their lives and, in turn, any responsibility that may come with those women. For Mr. Mizuno, he comes to see the woman in his life as disagreeable as soon as she is caught stealing something. It does not matter to $\mathrm{Mr}$. Mizuno that Sakiko sacrificed herself for him. Rather, their continued relationship would have potentially endangered his reputation if he kept spending time with her. He makes it clear to Sakiko that he does not want to be remembered by her. He even requests that she burn both the letter and the envelope he sent her. One reaches the end of the story and can safely assume that Mr. Mizuno will never see Sakiko again.

Like Mr. Mizuno, Dazai abandoned women without regard as to what was to happen to them after that. His first double suicide attempt was with a woman he barely knew (the woman was nineteen years old and married). In Dazai's writings about the event, there is a lack of emotion towards the woman at all. He once wrote that "It's a boring story. The woman killed herself because of the trouble she had in making a living. Until the very last minute when we jumped in we seem to have been thinking about 
entirely different things. ${ }^{, 59}$ In another example, after the failed attempt at a double suicide with Hatsuyo at the hot springs, Hatsuyo completely disappeared from Dazai's life, and the two never saw each other again. Hatsuyo gave up what she had with Dazai, and it seems as though there is no remorse, in fact, almost no emotion, on Dazai's part for Hatsuyo's loss.

There is one section of the text that could lead the reader to believe that Dazai did care about what happened to the women he abandoned. At the end of the story, Sakiko comments on her future, and the story ends in a hopeful tone:

In fact, I didn't feel miserable at all. On the contrary, I thought that, in the light of this humble lamp, my family was like a magic lantern, and I felt like saying "well, take a look at us, if you please. We make quite an attractive family, my parents and I." A quiet joy welled up in my heart, and I wanted to let it be known, even if only to the insects chirping in the garden. ${ }^{60}$

Sakiko's expression of happiness despite the adversity she faces suggests to the reader a sense of hope for her future. Knowing that she is at least capable of feeling better after all of the events with Mr. Mizuno is of some small comfort to her. Perhaps this was Dazai's way of coming to terms with his own abandoning of some of the women in his life. By creating a female character that could still be happy despite her abandonment, Dazai was perhaps able to assuage, in some small way, his guilt towards the women he had betrayed.

\footnotetext{
59 "The Flower of Buffoonery" ("Dōke no hana") was published originally in 1935 in The Japan Romantic School (Nihon romanha) magazine. See Keene, Dawn to the West, Volume 1, ibid., 1021.

${ }^{60}$ Gessel, ibid., 44.
} 


\section{Chapter 8 - "Truly, I Do Not Know Who Is the Real Me" - Identity and Recognition in "The Schoolgirl"}

"The Schoolgirl," though not one of Dazai's most well-known works, was highly praised when it was first published in 1939 in Literary World magazine. 61 "The Schoolgirl" even won the 1940 Kitamura Tōkoku Literature Award, which was the first literary award for Dazai since failing to win the coveted Akutagawa Prize years earlier. ${ }^{62}$ At first glance, like "Magic Lanterns," the story seems initially to share few similarities to Dazai's real life. However, there are many elements within the story that reflect Dazai's emotions towards family and society.

Though Dazai is credited with writing "The Schoolgirl," he took the idea from a school girl's diary. Ariake Shizu, who was nineteen years-old at the time, was a fan of Dazai's work and sent her diary to him to use as inspiration, which Dazai used as the basis of the plot of "The Schoolgirl." The story follows a day in the life of the unnamed narrator, a young woman whose father has died, and whose elder sister lives far away in Hokkaido. The story begins as she wakes up in the morning, goes to school, comes home, and ends with her going to sleep.

Throughout her day, the narrator has very few interactions with anyone around her, particularly at home. Because of this, the majority of the narration depicts only her stream-of-consciousness. The narrator describes her feelings about something, then

\footnotetext{
${ }^{61}$ Literary World magazine is one of the more literary magazines in Japan, orienting itself towards "pure literature" (jun bungaku).

${ }^{62}$ Dazai actually attempted to win the Akutagawa Prize on two separate occasions. His first attempt was at the first prize with his work "Losing Ground" in 1935, and his second attempt was at the third prize with his work The Declining Years in 1936 . Due to the February $26^{\text {th }}$ Incident - an attempted coup d'état by Imperial Troops aon the grounds that the government had been corrupted - the Akutagawa Prize, which is normally awarded twice a year, was only awarded once in 1935. Mack, ibid., 318.
} 
immediately corrects herself, and then reverts again to her original thoughts. This streamof-consciousness writing is evident from the first passage of the story, as the main character attempts to describe what she feels upon waking. Initially, she likens waking up in the morning to being found in a game of hide-and-seek. In the next sentence she retracts her simile, saying:

No, that's wrong, it's not that feeling, what is it, it's something more unbearable. When you open a box, and inside it there's another little box, and when you open that little box, again, inside that there's a smaller box, and when you open that, again, there's another smaller box, and when you open that little box, there's another little box, and so you go on opening seven, eight little boxes, and finally, at the end, there's a box as small as a die, and when you carefully open that, there's nothing, it's empty, that's a little what it's like. ${ }^{63}$

Immediately, the reader is aware that the narrator of this story has a pessimistic view on life. The narrator is also exceedingly isolated, speaking rarely to anyone, only to one or two friends at school. Returning home, she sees that her mother has guests, and hides herself away in the kitchen, cooking for them. Finally, she goes to sleep, leaving the reader to assume that the same process will repeat the next day.

The most apparent similarity between the narrator and Dazai is the pessimistic view in which the narrator addresses daily life. Dazai, who is famous for having said "I'm sorry for being born," shares this characteristic with the narrator. ${ }^{64}$ The narrator, also like Dazai, often critiques herself, but struggles with her perceived weaknesses:

\footnotetext{
${ }^{63}$ Dunlop, ibid., 1.

${ }^{64}$ The quote (in Japanese: Umarete, sumimasen), comes as the subtitle for his 1937 short story "Standard Bearer for the $20^{\text {th }}$ Century" ("Nijusseiki kishu”) DOZ, Volume 3, ibid., 39.
} 
My self-criticism up to now has been absolutely meaningless. When I try to criticize myself and I hit upon a weak, disagreeable trait, I immediately coddle it, indulge myself in it, feel sorry for myself. So the criticism comes to nothing. It would be more honest not to think about anything at all. $^{65}$

Dazai was known for holding the weakness humans have in high esteem. According to Ueda: "in [Dazai's] view, an evil person is a man who has no understanding of, and therefore no sympathy for, human weakness." ${ }^{, 66}$ Dazai, being a man of addictions and self-loathing, saw himself as a weak person. He saw that weakness as an essential human trait, not as a negative one. Dazai used weakness as a way to humanize the characters. This human weakness was something to be proud of, and, something in which one could find beauty.

Although the narrator decides that it is best not to indulge in self-criticism, she nevertheless continues vacillating between self-loathing and self-love. In one sentence, the narrator looks at herself in the mirror, and thinks “although I didn't even put on any rouge today my cheeks are flushed scarlet. And my lips, too, are gleaming small and red. I'm adorable. Taking off my glasses I smile quietly at myself. My eyes are very beautiful." 67 Then, in the next paragraph, her mood moves in the opposite direction: "In a rather buoyant mood I went to the kitchen. While I was rinsing the rice I grew sad all over again." ${ }^{68}$ Her changes in mood, from feeling good about herself to feeling bad in a short amount of time, are believable, especially for a junior high school girl who is just discovering herself. Dazai, like his schoolgirl, recognized how toxic his self-criticisms

\footnotetext{
${ }^{65}$ Dunlop, ibid., 8.

${ }^{66}$ Makoto Ueda, Modern Japanese Writers and the Nature of Literature, (Stanford: Stanford University Press, 1976) 150.

${ }^{67}$ Dunlop, ibid., 14.

${ }^{68}$ Ibid.
} 
were. He nonetheless based the majority of his writings on examining himself (or characters that were nearly identical to himself), including all of his faults. By indulging in self-critique, both Dazai and the narrator become trapped in their own worlds, losing the ability to objectively view themselves.

Like Dazai, the narrator of the story takes a certain amount of pride in her actions, which, for her, as with many young people, includes the effort in creating her appearance. On her way to school in a crowded train, the narrator feels that her furoshiki (wrapping cloth) deserves the attention of everyone in the car:

The furoshiki, in which I've wrapped my things today, I was given by my mother... It's a beautiful, feminine carrying cloth. Because it was beautiful I felt bad about tying it up. Sitting here like this, with the furoshiki on my lap, any number of times I steal a look at it. I stroke it. I want it to be seen by everybody on the trolley but no-one looks at it. ${ }^{69}$

The narrator, though introverted, still endeavors to be noticed and appreciated, even if for something as small as the beauty of her furoshiki. Her desire turns to disappointment when she feels that no one recognizes what she has to offer to the world.

Dazai too desired acknowledgment for his career accomplishments. The absence of his real parents when he was a child and the strict rules his brothers kept Dazai under once he was out of the household may have contributed to this need for recognition. The failure to win the Akutagawa Prize on three separate occasions was also a likely contributing factor. Dazai cataloged his upbringing, his career, and relationship failures in his writing, which is precisely how he eventually gained the recognition that he desired. Whether a literary accolade, or recognition from his family or respect from the people

${ }^{69}$ Ibid., 8 . 
around him, by writing about his desire for these things, Dazai was able to gain success. He was able to advance his career by writing about his shortcomings.

Initially, Dazai and the young woman seem may not to have anything in common, but there are many of similarities between the two of them. Although he may have taken his inspiration for the story from the diary of a young fan, the story is completely Dazaiesque, embodying many of his personal worries as well as his pessimistic outlook on life. The narrator also embodies Dazai's desire for recognition. She also shares his penchant for self-critique, as well as his idea that human weakness is a beautiful trait. 


\section{Chapter 9 - "Is He Even Sane?" - The Foolish Intellectual of "December 8 th"}

By 1938, Dazai was twenty-nine years old, and after the failed double suicide and subsequent divorce from Hatsuyo, he began to write with a newfound passion. In June of 1938, Dazai was remarried to Ishihara Michiko, who was twenty-six at the time. He had struggled to secure a place in the literary world, and that effort seem had paid off, with guest lectures at universities around Japan and his literature being published in numerous literary magazines. ${ }^{70}$ Even as the war in the Pacific escalated from the beginning of the 1940s (though Japan had been at war with China since 1937), Dazai avoided the writers' draft due to weak lungs and continued writing through the war period. ${ }^{71}$ His reinvigorated of enthusiasm is often attributed to his new bride. According to Lyons, Dazai "seems to have been at pains to reassure his wife and her family, who of course knew of his checkered past."72

After the attack on Pearl Harbor on December $7^{\text {th }}, 1941$ (December $8^{\text {th }}$ in Japan), Dazai was inspired to write another short story with a female narrator. At first glance,

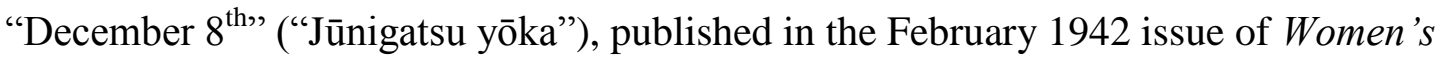
Opinion (Fujin kōron) magazine, appears to be a simple story of a housewife who is dealing with the realities of war. On closer inspection, however, the reader can see how

\footnotetext{
${ }^{70}$ As stated previously, Dazai won the Kitamura Tōkoku award for "The Schoolgirl.” In addition, in 1938 he won the a prize in the Nation's News newspaper's literature contest for his short story "Golden Landscape" ("Ōgon fükei"), with a prize of 50 yen (around $\$ 1,500$ by today's standards). His guest lecture positions took him as far as Niigata in northern Japan and at Tokyo Commercial University. Lyons, ibid., 42.

${ }^{71}$ The writers' draft was, according to Lyons, a "special journalistic service in lieu of military service," ibid., 43. If drafted, Dazai would most likely have been sent to China as a journalist, in the line of fire, but not as a soldier.

${ }^{72}$ Ibid., 42.
} 
Dazai has placed himself throughout the story. Specifically, Dazai used his narrator in order to express his doubts about his ability to please his new wife and her family.

The story follows a housewife who keeps a diary to record the attack on Pearl Harbor and subsequent declaration of war. Initially, she is not keeping a log to commemorate the war, but she is instead recording the " $2,600^{\text {th }}$ anniversary of Founding Day, ${ }^{, 73}$ marking the $2600^{\text {th }}$ year since Emperor Jimmu allegedly created the nation of Japan. ${ }^{74}$ She writes in the diary so that "in a hundred years when they're doing a grand celebration for the $2,700^{\text {th }}$ anniversary of the founding of our nation, maybe this diary of mine will be discovered in a corner of a storehouse somewhere, and they'll know that this is what a Japanese housewife was doing on this special day a hundred years ago, and it will serve as a little historical reference." ${ }^{, 75}$ The narrator goes on to describe the way she goes about her daily life. Her husband is a writer, although he, by her own account, is "not very dedicated, and so he doesn't bring in much of an income, just enough for us to get by from day to day." ${ }^{, 76}$ Her daily dissatisfaction towards her husband appears as a recurring theme throughout the text.

The reality of war sinks in while the young wife goes about her daily routine: distributing rations, going shopping, and relaxing at the public bath with her daughter, Sonoko. Her husband has generally been absent the whole day, causing a number of problems for his wife. She feels guilty when guests come by to visit her husband, and she must tell them that he is not available. She is also "disgusted" with him, a phrase which

\footnotetext{
${ }^{73}$ Dazai Osamu, trans. Phyllis Lyons, "December $8^{\text {th" }}$ The Columbia Anthology of Modern Japanese Literature, Ed. JT Rimer, (New York, NY: Columbia University Press, 2005) 660.

${ }^{74}$ Although Founding Day occurs on February $11^{\text {th }}$, the fanfare of the $2600^{\text {th }}$ continued well into the rest of the year. The narrator has most likely been keeping a diary since February 1940.

${ }^{75}$ Ibid.

${ }^{76}$ Ibid., 661.
} 
appears at least three times in the text. This disgust that the narrator feels becomes a major theme in the story and is brought up whenever the narrator talks about her husband.

Why does the narrator feel disgusted with her husband? She criticizes her husband for being pseudo-intellectual; although he is a writer, he constantly puts on airs to appear more intelligent than he is. His unawareness of basic facts undermines his attempts at sounding intellectual. When the narrator hears news of the attack by the Japanese forces, she calls to her husband to tell him the news:

But right away he answered back, "I know, I know." His tone of voice was harsh; he certainly seemed to be tense himself. He always stayed in bed until late in the morning; it was amazing for him to have awakened so early on this particular morning. They say that artists have strong intuitions... it rather impressed me. But then he went on to say something so awful, it canceled it out. "Where is the western Pacific? San Francisco, huh?"77

The husband is so oblivious to the world around him that he lacks even a simple grasp of geography. The reaction of his wife is strong because she has dealt with his attitude for so long that she is simply tired of it. Another reason for her disappointment is perhaps because, throughout the day, the narrator constantly needs to solve problems caused by her husband. Other than the many visitors who come to see her husband, to whom she must apologize for his absence, she also feels guilty towards one of her neighbors, Mrs. Kamei. The narrator expresses her feelings of guilt for the way Mrs. Kamei's husband has changed since the narrator's family has been living in the same area: "But then Mrs. Kamei's husband, quite unlike my own husband, did truly seem to love his family, and I felt envious. I hear that he loved them even more before, but ever since we moved into the neighborhood, my husband had gotten him into drinking...his wife must hate my

${ }^{77}$ Ibid., 662. 
husband, for sure."78 The guilt that the narrator feels towards both guests of her husband and towards her neighbors is a direct result of the husband's bad habits. Though she has no control over what he does, she must still deal with the consequences of his actions on a daily basis. The tension created by the narrator's required atonement for her husband's faults is noticeable in the interactions between her and her husband. The narrator's "disgust" comes from the guilt she feels for covering for his behavior.

One can note the apparent similarities between Dazai and the husband persona here in a number of biographical ways. At this point in time Dazai, though famous and making enough money to support himself and his new bride, still worked as a writer just as the narrator's husband did. Another similarity is that both Dazai and the narrator's husband lived in Mitaka, a suburban area of Tokyo. ${ }^{79}$ In these ways, although Dazai was not completely the same as the author in his story, there are numerous similarities that steer the reader to equate Dazai with the narrator's husband.

A different interpretation is that the narrator's husband is Dazai's tongue-in-cheek critique of intellectuals of the time. Dazai did not feel that he fit in with the Tokyo literary circles (bundan), nor did he feel comfortable with his own class background. For the former, Dazai could have used the character to criticize the writers who surrounded him, who were only interested in literature and in sounding intellectual. In 1946 Mishima Yukio, a rising literary star at the time, went out in Tokyo with Dazai and a group of his friends. Mishima was the one who was intent on discussing literature, whereas Dazai was "clearly bent on drinking as much as he could in as short a time as possible." Mishima

\footnotetext{
${ }^{78}$ Ibid., 664

${ }^{79}$ Mitaka is also where Dazai's grave is located: a site to where fans of his still flock to on his birthday to pay their respects.
} 
became angry and said "I don't like your literature," to which Dazai responded to his friends, "he must like my literature, or he wouldn't be here. ${ }^{80}$ Mishima apparently never forgot about Dazai's snub. Most likely, it was attitudes like Mishima's - the insistence on not taking a break from the intellectual lifestyle even while out for a drink - that Dazai was critiquing with his creation of the husband in "December $8^{\text {th }}$."

Whether Dazai was critiquing himself, the literary world, or husbands in general, he creates in "December $8^{\text {th" }}$ a narrator who has become "disgusted" with her own husband because of his pseudo-intellectual tendencies. The dynamic established in "December $8^{\text {th }}$ of a strong wife having to make up for her weak husband became a topic that Dazai would revisit in later works, including his short story "Villon's Wife."

${ }^{80}$ Lyons, The Saga of Dazai Osamu, ibid., 144, as taken from Henry Scott-Stokes, The Life and Death of Yukio Mishima (New York: Farrar, Straus \& Giroux, 1974), 115-16 and John Nathan, Mishima: A Biography (Boston: Little, Brown \& Co., 1974), 92-93. 


\section{Chapter 10 - "Women Don’t Know Anything about Happiness or Unhappiness" - "Villon's Wife"}

In the post-war years, Dazai's personal life suffered a number of blows. When his elder sister died he returned to Tsugaru for the funeral and ended up staying away from Tokyo for a year and a half. Upon return to Tokyo, his friend and fellow author Oda Sakunosuke died of a lung hemorrhage at the age of thirty-four. Dazai also rekindled an affair with Ota Shizuko, and often left his family to spend time with her in Shizuoka. Dazai's works from this period of time until his death "reflect an intensification of the tone of defeat and nihilism" already found in his works. ${ }^{81}$ It was in this dark phase of his life that Dazai wrote two of his most famous works, the novels The Setting Sun and No Longer Human (Ningen shikkaku).

In another short story published in 1947, Dazai further explores the husband and wife dynamic he established in "December $8^{\text {th }}$." In "Villon's Wife," the narrator Sacchan struggles with her husband's drunken misgivings. The story is about her solitary quest to right a wrong done by her husband. Her husband, Ōtani, has been drinking at a small tavern for years without paying. One night, he even goes as far as to steal money from the owners, and then runs away to his home. The couple follows him back to his house to confront him. Ōtani then becomes violent and brandishes a knife before running off into the night. He leaves Sacchan alone to pacify the couple on her own. She promises to pay back the money by working at the bar, slowly paying back her husband's tab in the process. Eventually, Ōtani becomes a good patron to the bar, drinking quietly alone and then walking Sacchan home at the end of each night.

\footnotetext{
${ }^{81}$ Lyons, ibid., 50.
} 
The relationship between Sacchan and Ōtani seems to be better than it was at the story's beginning because of Sacchan's employment. However, the tranquil relationship changes one night when Sacchan walks home without Ōtani, is followed by a customer, and then is raped by him. The next day, she goes to work and finds her husband there and informs him that, from now on, she will be living at the bar. Ötani agrees that is the best course of action. He then abruptly changes the subject, commenting on how he has been scandalized in the day's newspaper and called a monster. In the last line of the story, Sacchan says, "There's nothing wrong with being a monster, is there? As long as we can stay alive." 82 One could interpret the story as ending on a positive note, however that is not the case. Rather, Sacchan's words are a sign that her narrative has come full-circle; she has lost the joy she had found both in her work and with Ötani, and the two have returned to the misery seen at the start of the story.

Here, Dazai's often-used dynamic between husband and wife unfolds just as it did in "December $8^{\text {th }}$." Sacchan appears as caretaker for her husband, instead of a romantic partner. Not only does she care for her husband financially (for example, in regards to the bar tab), but she also attempts to support him emotionally. Despite Sacchan's kindness, Ōtani spends the majority of his time away from their home. Sacchan explains her and her child's predicament in the following way:

${ }^{82}$ Keene, Modern Japanese Literature, ibid., 414. 
Now the boy is growing up fatherless, while my husband goes off for three or four nights or even for a whole month at a time. I don't know where he goes or what he does. When he comes back he is always drunk; and he sits there, deathly pale, breathing heavily and staring at my face. Sometimes he cries and the tears stream down his face, or without warning he crawls into my bed and holds me tightly. 'Oh, it can't go on. I'm afraid. I'm afraid. Help me!"83

Sacchan endeavors to be patient with Ōtani's mental instability. In addition to her emotional support of him, in order to make up for her husband's spending habits, she must help them with their finances by relying on his publishers and editors, who regularly come to Ōtani's house with money for Sacchan and her child. Similarly Dazai, until he was finally able to support himself with his writing, was financially dependent on others. Aside from typical financial support by his affluent family, Dazai was known for borrowing money from anyone who would lend it to him, including his mentor Ibuse Masuji, and even his editors. ${ }^{84}$

A main theme in the story is Ōtani's awareness of how he and his work are viewed by the public. After Sacchan starts work at the tavern, Ōtani sometimes walks her home at night. One night, Sacchan brings up the joy she has now that she is working. Ōtani responds, commenting on his own work as a writer, and says “My work doesn’t mean a thing. I don't write either masterpieces or failures. If people say something is good, it becomes good. If they say it's bad, it becomes bad." ${ }^{85}$ Ōtani recognizes that the personal effort he puts into his work is not the only deciding factor as to a work's success. Dazai's own feelings towards the media, and in particular literary reviewers, are perhaps reflected in Ōtani's sentiments written here.

\footnotetext{
${ }^{83}$ Ibid., 406

${ }^{84}$ Lyons, ibid., 124.

${ }^{85}$ Keene, Modern Japanese Literature, ibid., 412.
} 
Another instance of Ōtani's awareness of the media occurs at the end of the story when Sacchan returns to the tavern at the end of the story to find her husband sitting there reading the paper. He comments on the way he is written about in the media: "Well what do you know. They're writing bad things about me again. They call me a fake aristocrat with Epicurean leanings...Look! It says here that I'm a monster. That's not true, is it?"86 Ōtani and Dazai were both criticized by fellow members of the literary world. In addition to the Kawabata incident, Dazai also faced criticism from a former mentor, Satō Haruo. Satō was also on the committee to select the first winner of the Akutagawa Prize. Before the selection process began, Dazai wrote to Satō about his strong desire to win the Prize. He also made several visits to the author's home. ${ }^{87}$ Satō publicly responded to Dazai about the latter's unorthodox behavior, publishing his reactions in Restructure (Kaizō) magazine. In Mack's estimation, “while Kawabata's and Satō's actions suggest that they respected Dazai's ability... they nonetheless showed little hesitation in exposing his desperation to readers. ${ }^{\prime 88}$ The Akutagawa Prize criticisms still affected Dazai ten years later, made evident by Dazai placing Ōtani in a similar situation of judgment by critics.

Dazai and Ōtani also shared a trait, nihilism, which dominated their personalities. On one of their walks home together, Sacchan talks about her happiness with her new life at the tavern. Ôtani counters her claim and says that "Women don't know anything about happiness or unhappiness. ${ }^{" 89}$ When Sacchan asks about men, Ōtani says that "men only

\footnotetext{
${ }^{86} \mathrm{Ibid}, 416$.

${ }^{87}$ Mack, ibid., 315.

${ }^{88}$ Ibid.

${ }^{89}$ Keene, Modern Japanese Literature, ibid., 411.
} 
have unhappiness. They are always fighting fear. ${ }^{, 90}$ On one hand, Ōtani is saying that men are only capable of being unhappy. On the other hand, Ōtani is commenting that women are in a better situation because, although they are incapable of happiness, they are at least blissfully unaware of being unhappy, as well. Ōtani's remarks are reminiscent of Dazai's comments on women in his essays and in particular, his story "Womankind," in which he says that women are incomprehensible, and that it would be better if they were classified in a separate category from men.

In the same conversation between the two, Ōtani says, "Ever since I was born I have been thinking of nothing but dying. It would be better for everyone concerned if I were dead, that's certain. And yet, I can't seem to die. There's something... which won't let me die. ${ }^{91}$ Here, the parallels between the two men are immediately apparent. Dazai attempted to commit suicide no less than five times during his life, the earliest known attempt being in his teens. Perhaps Dazai's own experience of surviving so many suicide attempts created a similar feeling - namely, that something was preventing him from dying - to the one expressed by Ōtani in the story.

In the case of "Villon's Wife," unlike other examples of Dazai's female narrators, the narrator of the story is separate from the main character. Although the story is told through the eyes of Sacchan, the main character is certainly Ōtani. In "December $8^{\text {th }}$," the narrator is the main character, even when the relationship with the husband is a central theme. This is because readers also are able to experience thoughts by the narrator that have nothing to do with her husband, such as her own opinions about the announcement

\footnotetext{
${ }^{90}$ Ibid.

${ }^{91}$ Ibid., 412.
} 
of war, and her feelings about Japan and the threat of invaders. Though both similar in plot, the focus on the husband - not the wife - distinguishes "Villon's Wife" from the earlier "December $8^{\text {th }}$." Whereas they both are narrated by female characters, the plot in "Villon's Wife" is focused on Ōtani, the husband.

The focus on Ōtani and the lack of focus on Sacchan's feelings is different from the works previously analyzed here. Every element of the story is directly linked to Ōtani, and he becomes the catalyst for almost all of Sacchan's motivations. The reason that Sacchan goes to work at the tavern is to pay back Ōtani's bill. Her happiness from her work comes from Ōtani's newfound respect and appreciation for her at her work. Even when Ōtani is not physically present in the story, he is still the focus of the plot. When the couple come to Ôtani's house, and he runs away, the couple explain to Sacchan why Ōtani owes them the money. The bar owners' retelling of events takes up a large portion of the text, in which Sacchan's role as narrator is usurped by them, thus Ōtani's story overrides her own story and narrative authority. Even Sacchan's rape occurs in part because of Ōtani's absence. Because Ōtani was unavailable to walk Sacchan home that night, she was put in a situation for the rape to happen. Ötani is the center of the story, and Sacchan, even more so than the other female narrators, seems to simply provide the role of medium, rather than being the main character. 


\section{Chapter 11 - Deviation from Established Patterns: The Setting Sun}

"Villon's Wife" was one of the last stories Dazai wrote; he was to commit suicide following year. Shortly after "Villon's Wife," Dazai published one of his most wellknown novels, The Setting Sun. The novel is about Kazuko, the daughter of an aristocratic family who, due to the social and political reforms occurring in Japan postwar, is forced to move with her mother from Tokyo to the countryside. The story catalogues their struggles to find normalcy in their new lives. To complicate things, Kazuko's brother, Naoji, who has been off at war, returns. He has replaced his opium addiction with alcoholism, and spends what is left of their family's money in the pleasure districts of Tokyo. Another critical character in the story is Uehara, an author who is more concerned with drinking than writing. He serves as Kazuko's main love interest.

For two reasons, The Setting Sun will not be discussed at length in this paper. First, because of the notoriety of The Setting Sun, it has been analyzed by numerous scholars since its publication in $1947 .^{92}$ The second reason is that, in terms of female narrators Dazai used in his other works, The Setting Sun deviates from the previously established narrative patterns using female narrators. Kazuko is indeed a female narrator and there are male characters that are similar to Dazai. However, the binary of criticcritiqued (e.g., a non-Dazai character critiquing a Dazai persona) is not as clearly established in The Setting Sun. Rather, Dazai embodies all of the central characters at the same time.

\footnotetext{
${ }^{92}$ Donald Keene, the original English translator for The Setting Sun and other Dazai stories, devotes a number of pages to analysis in Dawn to the West, ibid., Volume 1. In addition, Both Phyllis Lyons and James O'Brien cover the contents of the novel and have in-depth and accurate analyses of the story, in The Saga of Dazai Osamu and Dazai Osamu, respectively.
} 
In the works presented thus far, Dazai uses the female narrator largely as a vehicle to describe a character that is similar in some way to himself. There is a slight deviation from the critic-critiqued pattern in "The Schoolgirl," because it is the narrator herself who possesses the Dazai-like traits. Because of this, the narrator plays the role of both the critiquing woman and the critiqued Dazai persona. In The Setting Sun, however, "one may easily form the impression that although the characters of Kazuko, Naoji, and the novelist Uehara are distinctly drawn, they are all transmutations of Dazai himself."93 Kazuko is a rebellious child of an affluent family, more compassionate towards the working class people than with the aristocrats of her pre-war life. She lives in the periphery, neither a part of the proletariat nor the upper class. Her brother Naoji is a nihilist, who was also addicted to an opiate for a long period of time. ${ }^{94}$ In addition, the name "Naoji" shares a kanji character with Dazai’s first name, "Osamu," a literary tactic Dazai often utilized to further strengthen the reader's connection between him and his character. ${ }^{95}$ Finally, Uehara is a novelist who spends more time in bars than he does on his work, and who is certainly an alcoholic like Dazai.

As Keene points out, within the novel, Dazai creates versions of himself in almost every central character; it is simply a matter of to what degree a character has been infused with the essence of Dazai. Kazuko's sympathy towards the proletariat and extensive knowledge of literature are qualities that are deeply reminiscent of Dazai. It is difficult to analyze The Setting Sun with the critic-critiqued binary. In The Setting Sun,

\footnotetext{
${ }^{93}$ Keene, Dawn to the West, Volume 1, ibid., 1061.

${ }^{94}$ There is a scene in The Setting Sun where Kazuko reads a journal that Naoji kept while suffering withdrawals from opium. This chapter is largely taken from Dazai's own writings while admitted to a hospital for his addiction to pain killers.

${ }^{95}$ The kanji character is also present in Dazai's given name, Shūji.
} 
the clear distinction is blurred between those who critique the Dazai persona and those who have the Dazai persona.

Because every central character within The Setting Sun is imbued in some way with Dazai-like traits, the binary of critic-critiqued is not applicable in this novel. In his other works, Dazai uses his other female narrators specifically because of their close relationships with the Dazai personae; they are able to critique the Dazai personae from an outside, specifically non-male, perspective. But in The Setting Sun, because all of the characters are in essence Dazai personae, the novel could have been written from the perspective of any one of them, and the result would still be the same. Kazuko is a woman, that is true, but she is simply another stand-in for Dazai. If the story were being told from Naoji's perspective, he would still be able to comment on the Dazai-like traits present in Kazuko and Uehara, and the binary of critic-critiqued would still be present. The swapping of narrators would not be possible in "Villon's Wife," for example, because Sacchan does not possess any prominent Dazai-like characteristics. For this reason, The Setting Sun deviates so much from the previously established pattern of female narrators utilized by Dazai that it is not applicable to this study. 


\section{Conclusion: The Role of Women in Dazai's Narratives and Beyond}

My research thus far has taken me to a number of sources, all of whom are experts on Dazai, who have written on a number of different facets in the author's life and work. However, with the exception of Kazuko in The Setting Sun, the female narrators found within his works have not been analyzed to any great extent. The question of why Dazai chose to utilize a female narrator has not occupied the majority of scholarship on Dazai in English. The most extensive investigation on the subject comes from Phyllis Lyons and her speculations on why Dazai chose to rely so heavily on female narrators towards the end of his career. Although Lyons critically analyzes why Dazai chose these female narrators, her conclusions for his motives are different from my own.

Of the four stories analyzed in this paper, the majority were written by Dazai during either the prewar or interwar periods. This leaves only "Villon's Wife" in the category of "late works by Dazai" that Lyons analyzes. Of Sacchan, Lyons states that "[She] is perhaps Dazai's fullest female portrait"96 and discusses Sacchan's transformation throughout the text. Though Lyons is persuasive in her analyses, she neglects one important factor. As previously stated, the main character of the story is not Sacchan, but Ōtani. Sacchan's role, then, becomes simply a medium through which to tell the story of Ōtani. The story is advanced by Ōtani's actions, or lack thereof, and all of the characters in the story exist within a web, with Ōtani at the center. It is not important that Dazai imagined Sacchan in great detail, because she functions as a signpost, redirecting the reader's attention from her to Ōtani.

\footnotetext{
${ }^{96}$ Lyons, ibid., 164.
} 
Lyons states, quite correctly, that in "Villon's Wife," the character of Ōtani comes across as "simply selfish and childish." ${ }^{97}$ Ōtani's transgressions are fully revealed within the text; everything that he has done wrong is there for the reader to see. However, in Dazai's world, where beauty is found in human weakness, it is specifically Ōtani's weaknesses - his constant disappointing Sacchan, his financial irresponsibility, and his emotional frailty - that make him a more compelling character. Dazai once criticized Shiga Naoya, saying, "He does not understand the beauty of weakness." 98 It would make sense, then, that Dazai would have a weak character as the center of his story, with Sacchan as an opposite, strong character to be used for contrast. Sacchan, a strong character, lacks Ōtani's negative traits, therefore she does not appear as a fully-rounded character like Ōtani.

The binaries that Dazai used in his female-narrated stories of the weak man and the strong woman were not created in an attempt to empower women of the time. Rather, Dazai used them simply as a means to further critique Dazai himself. As Lyons says, Sacchan is indeed a very detailed character, more so than many of his female narrators. She is pure, and kind, and is always striving to survive. In contrast, Ōtani is deathobsessed, cruel, and selfish. If Sacchan were not in the story, or if her personality were similar to Ōtani's, then the critique of a character so similar to Dazai would not be as stark, and the effect would not be as easily seen. Dazai was not creating strong female characters for the purpose of supporting a positive image for women in literature. He was

\footnotetext{
${ }^{97}$ Ibid.

${ }^{98}$ Ueda, ibid., 150.
} 
creating a strong image of women to further contrast the weakness of the men in his stories.

Though the plots of "Villon's Wife" and "December $8^{\text {th" }}$ are comparable, the ways in which Dazai presents his persona in the text is not the same. In "December $8^{\text {th }}$," the narrator critically views how her husband - the writer and intellectual - spends his days completely oblivious to reality. Through her eyes, he is concerned only with preserving his illusion of intelligence. According to his wife, he seems unaffected by either the start of the war or by the hardships he has created for her. In this work, the author-character can stand for Dazai, but he can also represent intellectuals as a whole. Given Dazai's many negative encounters with fellow writers, the disdain that is displayed for pseudo-intellectuals by the narrator of "December $8^{\text {th" }}$ could be interpreted as Dazai's own feelings about this class of people. Dazai's tongue-in-cheek interpretation of a writer who is too preoccupied with sounding intellectual to produce any work is a prime example of Dazai using a strong narrator to critique a weak man.

Dazai toyed with his past in his works and used his experiences as a springboard for his fiction. His looseness with the facts allowed him to deviate from his own past and thereby create characters imbued with exaggerated versions of Dazai's own personality. In "Magic Lanterns," Dazai explores what existed inside him that made it so easy for him to abandon the women who loved him. In the same way that Dazai left Hatsuyo, or was able to walk away from his attempted double suicide with Shimeko, Mr. Mizuno abandons Sakiko, ordering her to erase all memories of him. It is difficult for the reader to comprehend how Mr. Mizuno could so easily rid himself of Sakiko, but his cruelty is 
what makes him a compelling character. His cruelty is another reminder of the human weakness Dazai so valued.

"The Schoolgirl," though diverging from the typical binaries seen in Dazai's female-narrated works, is still an effort on Dazai's part to explore a different facet of his personality. Within the emotional twists and turns of an adolescent girl, Dazai had the perfect opportunity to further explore his feelings of being an outsider, who desperately craved validation from the people around him. The narrator daintily holds her furoshiki on the train, quietly seeking attention and admiration from those around her that will not come. She warns of the pitfalls of self-critiquing, while at the same time indulging in it herself, to the point of, as she puts it, "coddling" her weaknesses. There is a sense of purpose in Dazai's choice of a female narrator: taking a teen girl's supposed emotional fickleness as a backdrop, Dazai is able to rapidly delve into feelings of happiness, sadness, longing, anger, jealousy, satisfaction and pessimism in this short work. Dazai uses the female narrator as a mirror, representing his own penchant for self-critique, and for the beauty to be found in human weakness.

Childhood friends of Dazai recall him talking constantly about himself and his family, so the fact that the majority of Dazai's works are taken from events in his own past is no surprise. ${ }^{99}$ One may conclude through the analyses of these four femalenarrated texts that they are no exception to the majority of his corpus because they focus on a selfish, male, Dazai-like character. However, the difference between his malenarrated works and his female-narrated works is the degree of separation that lies between the narrator and the Dazai persona. By utilizing a strong female narrator to

${ }^{99}$ Lyons, ibid., 55. 
observe the Dazai-like character, the human weakness in the Dazai persona becomes more apparent. Through the critic-critiqued binary, Dazai was able to accentuate the weaknesses of his male protagonists by contrasting them with the strengths of his female narrators. His female narrators acted as conduits between Dazai and the reader, allowing the reader to explore the author through his works, but through the lens of another.

There are other works in which Dazai employed the use of female narrators that were not covered in this research that could strengthen my hypothesis. Looking beyond Dazai to a broader scope, tracing Japanese novelists' usages of narrators of the opposite sex, and to what end they may have done so, is another area I would like to study. Even though Dazai used female narrators to critique himself or his Dazai personae, that does not mean that other male writers utilizing female narrators were doing it for the same reason, and exploring to what end other authors used female narrators would create a fascinating case study. Further research into gender swapping in literature could possibly shed light on gender relations in Japan throughout history, as well as what gender in Japanese society means today. 


\section{Selected Bibliography}

Beauvoir, Simone, and H M. Parshley. The Second Sex. New York: Alfred A. Knopf, 1993.

Butler, Judith. Bodies That Matter: On the Discursive Limits of "Sex". New York: Routledge, 1993.

---. Gender Trouble: Feminism and the Subversion of Identity. New York: Routledge, 1990.

Cixous, Helene and Jenson, Deborah. "Coming to Writing" and Other Essays. Cambridge, Mass Harvard University Press, 1991.

---. and Sellers, Susan. The Hélène Cixous Reader. New York, NY: Routledge, 1994.

Copeland, Rebecca L. Woman Critiqued: Translated Essays on Japanese Women's Writing. Honolulu: University of Hawai'i Press, 2006.

Dazai Osamu. Dazai Osamu Zenshū. Tokyo: Chikuma Shobo, 1955.

---. Trans. Phyllis Lyons. "December $8^{\text {th }}$," in The Columbia Anthology of Modern Japanese Literature. Ed. J.T. Rimer and Van C Gessel New York, N.Y: Columbia University Press, 2005.

---. Joseito. Tōkyō: Nihon Tosho Sentā, 2002.

---. Trans. Tomone Matsumoto. "Magic Lanterns," in The Shōwa Anthology: Modern Japanese Short Stories. Ed. Van C. Gessel and Tomone Matsumoto Tokyo: Kodansha International, 1985.

---. Trans. Lane Dunlop. “The Schoolgirl.” Newcastle upon Tyne, England: Northern House for Stand Magazine, 1992.

---. The Setting Sun. Trans. Donald Keene. New York: New Directions Publ. Corp, 1968.

---. Trans. Donald Keene. "Villon's Wife," in Modern Japanese Literature: An Anthology. Ed. Donald Keene. New York, NY: Grove Press, 1994.

Foucault, Michel, Donald F. Bouchard, and Sherry Simon. Language, Counter-Memory, Practice: Selected Essays and Interviews. Ithaca, N.Y: Cornell University Press, 1977.

Fowler, Edward. The Rhetoric of Confession: Shishōsetsu in Early Twentieth-Century Japanese Fiction. Berkeley: University of California Press, 1988. 
Hiratsuka, Raichō. Trans. Teruko Craig. In the Beginning, Woman Was the Sun: The Autobiography of a Japanese Feminist. New York: Columbia University Press, 2006.

Ihara Saikaku. Trans. Paul Schalow. The Great Mirror of Male Love. Stanford, Calif: Stanford University Press, 1990.

Itō, Ken K. Visions of Desire: Tanizaki's Fictional Worlds. Stanford, Calif: Stanford University Press, 1991.

Karatani Kōjin. Origins of Modern Japanese Literature. Durham, N.C: Duke University Press, 1993.

Keene, Donald. Dawn to the West: Japanese Literature of the Modern Era, Volume 1. New York: Holt, Rinehart, and Winston, 1984.

---. Seeds in the Heart: Japanese Literature from Earliest Times to the Late Sixteenth Century. New York: Henry Holt \& Co, 1993.

Leiter, S L. "From Gay to Gei: the Onnagata and the Creation of Kabuki's Female Characters." Comparative Drama. 33 (2000): 495-514.

Levy, Indra A. Sirens of the Western Shore: The Westernesque Femme Fatale, Translation, and Vernacular Style in Modern Japanese Literature. New York: Columbia University Press, 2006.

Lowy, Dina. The Japanese "New Woman": Images of Gender and Modernity. New Brunswick, N.J: Rutgers University Press, 2007.

Lyons, Phyllis I. "'Art Is Me': Dazai Osamu's Narrative Voice as a Permeable Self." Harvard Journal of Asiatic Studies. 41.1 (1981): 93-110.

---. The Saga of Dazai Osamu: A Critical Study with Translations. Stanford, Calif: Stanford University Press, 1985.

Mack, Edward. "Accounting for Taste: the Creation of the Akutagawa and Naoki Prizes for Literature." Harvard Journal of Asiatic Studies. 64.2 (2004)

Mackie, Vera C. Feminism in Modern Japan: Citizenship, Embodiment, and Sexuality. Cambridge: Cambridge University Press, 2003.

McCarthy, Ralph F. Self Portraits: Tales from the Life of Japan's Great Decadent Romantic. Tokyo: Kodansha International, 1991. 
McNay, Lois. Foucault and Feminism: Power, Gender, and the Self. Boston:

Northeastern University Press, 1993.

Mishima Yukio. Trans. Meredith Weatherby. Confessions of a Mask. New York: New Directions, 1958.

Molony, Barbara, and Kathleen S. Uno. Gendering Modern Japanese History.

Cambridge, Mass: Harvard University Asia Center, 2005.

Morgan, Thaïs E. Men Writing the Feminine: Literature, Theory, and the Question of Genders. Albany: State University of New York Press, 1994.

Morinaga Maki. "The Gender of Onnagata As the Imitating Imitated: Its Historicity, Performativity, and Involvement in the Circulation of Femininity." Positions: East Asia Cultures Critique. 10.2 (2002): 245-284.

O'Brien, James A. Dazai Osamu. New York: Twayne Publishers, 1975.

Paglia, Camille. Sexual Personae: Art and Decadence from Nefertiti to Emily Dickinson. New Haven: Yale University Press, 1990.

Pyle, Kenneth B. The Making of Modern Japan. Lexington, Mass: D.C. Heath, 1996.

Rubin, Jay. Injurious to Public Morals: Writers and the Meiji State. Seattle: University of Washington Press, 1984.

Sartre, Jean-Paul. Trans. Hazel Barnes. Being and Nothingness: An Essay on Phenomenological Ontology. New York: Philosophical Library, 1956.

Sato, Barbara H. The New Japanese Woman: Modernity, Media, and Women in Interwar Japan. Durham, N.C.: Duke University Press, 2003.

Suzuki, Tomi. Narrating the Self: Fictions of Japanese Modernity. Stanford, Calif: Stanford University Press, 1996.

Tanizaki Jun'chiro. Trans. Anthony H. Chambers. Naomi: A Novel. San Francisco: North Point Press, 1990.

---. Trans. Howard Hibbelt. Quicksand. New York: Alfred A. Knopf, 1994.

Tomida, Hiroko, and Gordon Daniels. Japanese Women, Emerging from Subservience, 1868-1945. Folkestone, Kent: Global Oriental, 2005.

Tyson, Lois. Critical Theory Today: A User-Friendly Guide. New York: Routledge, 2006. 
Ueda, Makoto. Modern Japanese Writers and the Nature of Literature. Stanford, Calif: Stanford University Press, 1976.

---. The Mother of Dreams and Other Short Stories: Portrayals of Women in Modern Japanese Fiction. Tokyo: Kodansha International, 1986.

Walters, Margaret. Feminism: A Very Short Introduction. Oxford: Oxford University Press, 2005.

Wolfe, Alan S. Suicidal Narrative in Modern Japan: The Case of Dazai Osamu.

Princeton, N.J: Princeton University Press, 1990. 